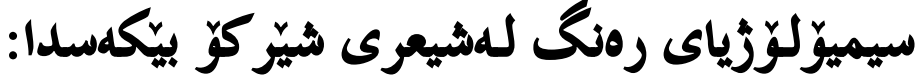 \\ * ديوانى رهندان به نموونه
}

\section{Colour Semiotics in Sherko Bekas's Poetry: Rangdan Collection as an Example}

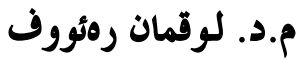 \\ بإيمانكهى تهكنيكى كوردستان \\ Lecturer Dr. luqman raouf \\ Kurdistan Technical Institute \\ E-mail: luqman.ali@kti.edu.krd
}

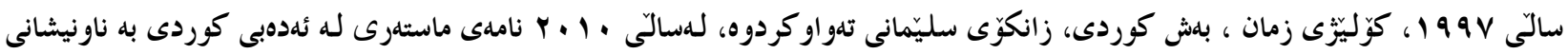

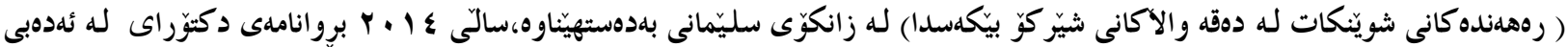

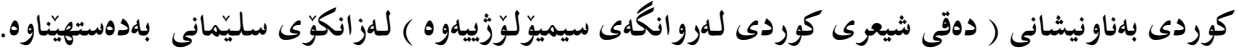

بلأوكراوه:

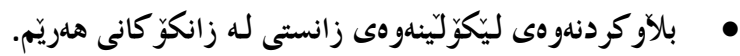

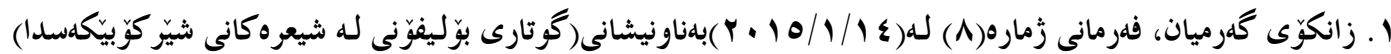

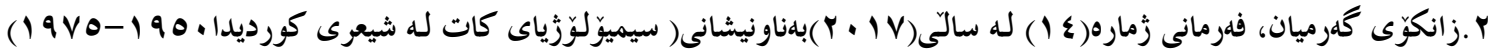

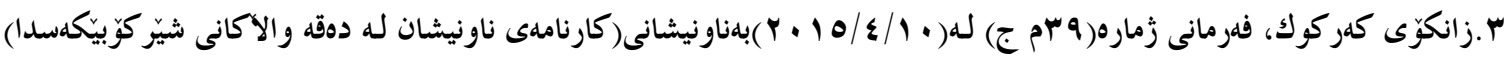
http://www.iasj.net/iasj?func=issueTOC\&isld=6550\&uiLanguage=ar

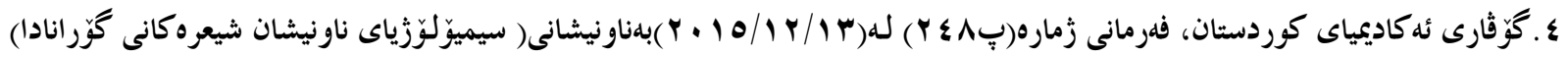
http://kaj.kissr.edu.krd/en/PartA/journallssues.php

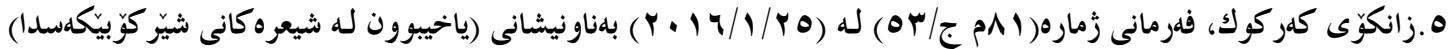

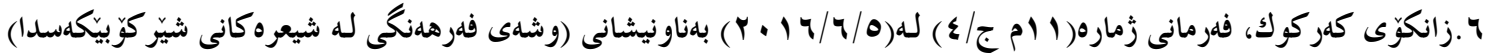

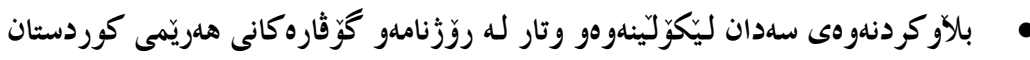

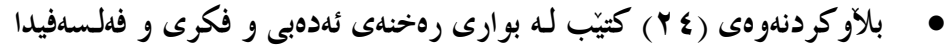
http://www.slideshare.net/luqmanraouf/edit_my_uploads

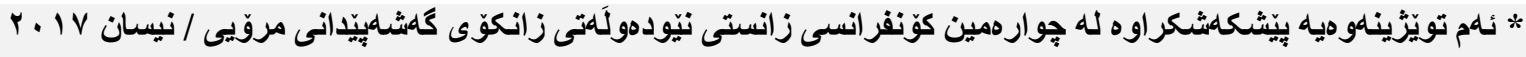




\title{
الملخص
}

سيميولوجيا هي احدى النظيات الحيوية ما بعد الحداثة من خلال العلامات و مميزاتها، فإنه يتغلغل بعمقه نحو المعاني

العميقة للنص.

ديوان رقنطدان للشاعر شيَركؤ بيَكةس هي واحدة من هذه الجمموعات ذات العلامات المميزة، لأن الشاعر استخدم

9 ا Y ا الألوان و العديد من الكلمات كعلامات مميزة فى قصيدة. اغلبية الألوان المستخدمة فى قصيدة هي الأزرق،الأسود،

الأمر ، الأبيض.

لكل لون من هذه الألوان لها معانيها الخاصة وآثارها الدقيقة مختلف الثقافات و النصوص ، حيث كان لها الاثر

الفعال على اراء الناس، فهو يقوم بتصوير دور الالوان و علاقتة بحياة الناس، وهكذا فان استخدام رةنطدان و التى تعنى باقة الوان لا تخلو من الهدف، و لكنها تطرق بكل ماله من علاقة بالجوانب البيئية والنفسية والفكرية والثقافية للحياة.

\begin{abstract}
Semiotics is one of the modern critical methods of postmodernism in which through signs, it digs deep into the depth of a text.Sherko Bekas's Rangdan collection is one of the collections in which signs are used abundantly because the poet uses colours 1219 times and many words are used as signs. The most used colours are blue, black, red and white. Each of these colours has its own meanings and implications in different cultures and texts; it has its role on people's views, and it depicts roles of colours in relations to the lives of people. Hence, the use of Rangdan, which means the collection of colours, is not without purpose, but it has everything to do with environmental, psychological, intellectual and cultural aspects of life.
\end{abstract}

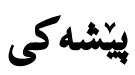

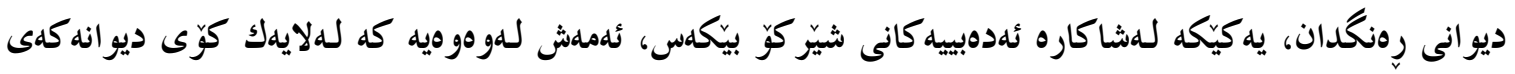

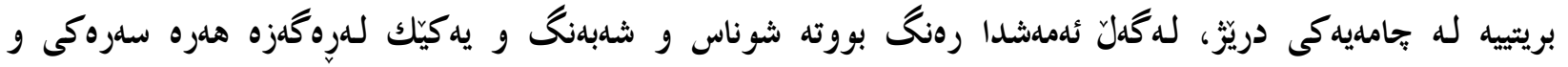
ديارهكانى جوانناسى و سهرنجِ اكيّشى و بلهمدلولكردنى كوّى ديوانه كهى شاعير، هلر للهبهرئهمهشه ديوانهكهى ناوناوه

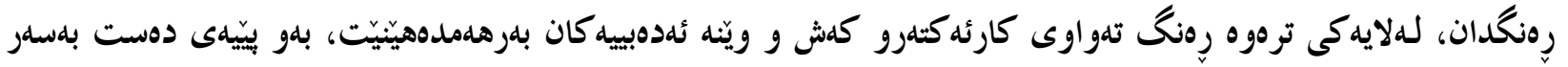

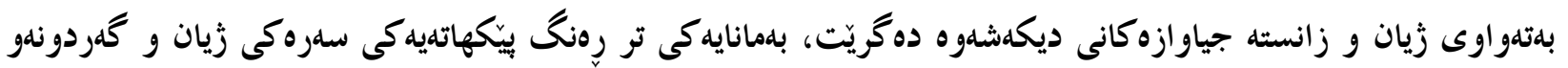

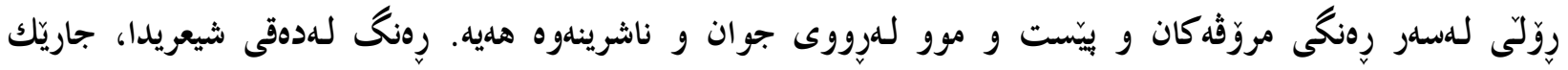

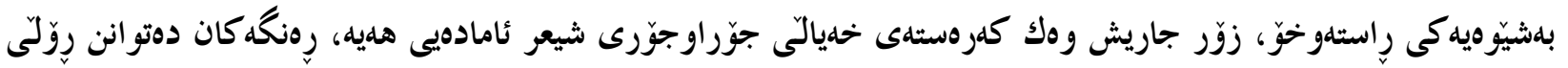

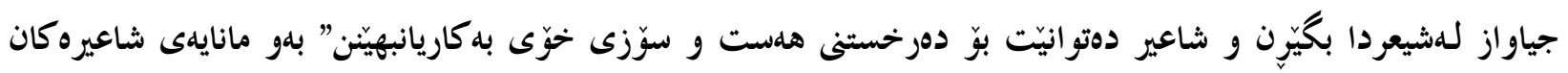

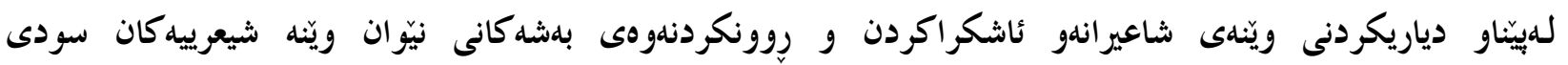




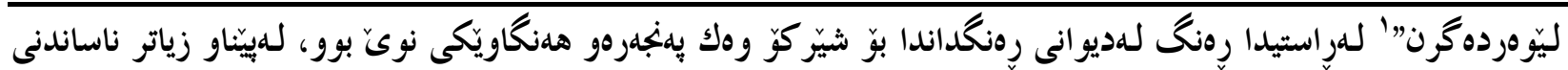

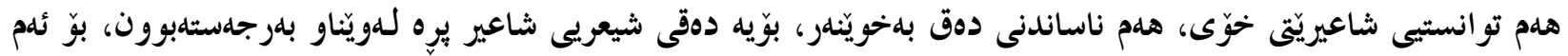

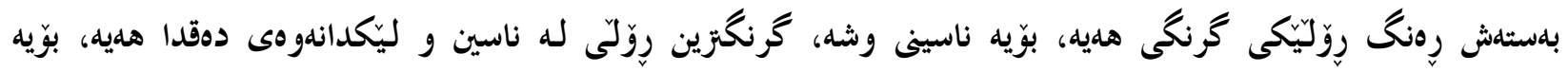

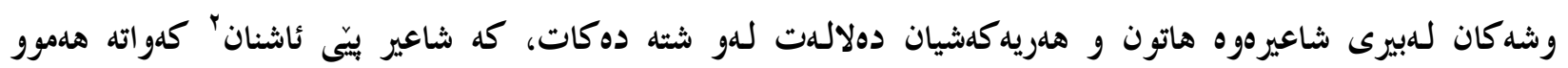

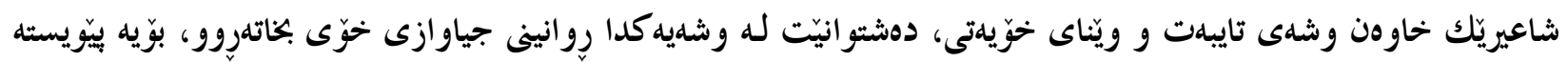

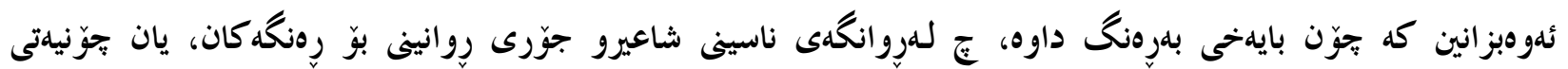

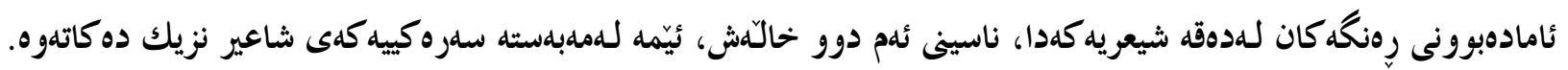

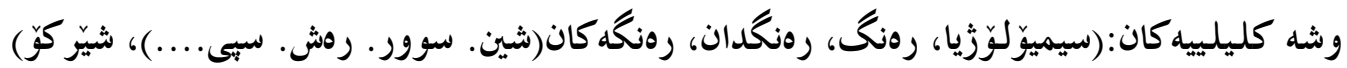

\section{تُامانجى ليَكوَّلينهوه:}

ا -

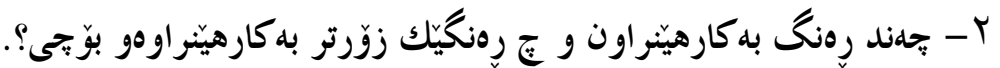

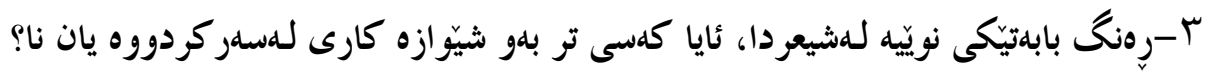

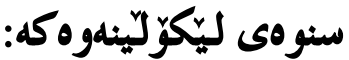

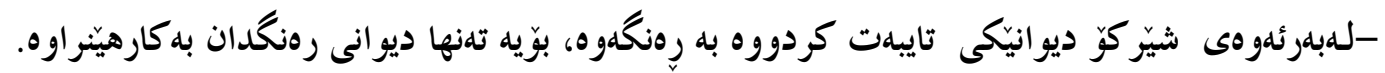

\section{ميتوّدى ليّكوَّلِينهوه كه:}

-بلهوبيّيهى كاركردنه للهسهر ليّكدانهوهى دهق و دياريكردنى رهنگ وهك نيشانهو خستنهروورى ئامار، بوّيه

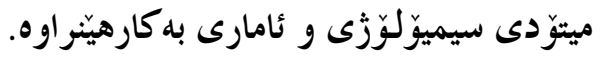

\section{جهمك و ريّيّاسهى سيميوّلَّزيا:}

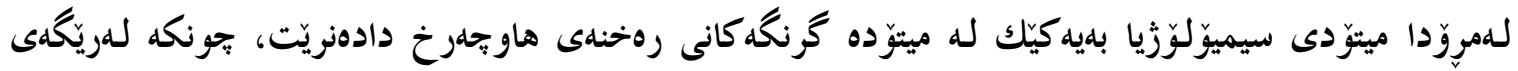

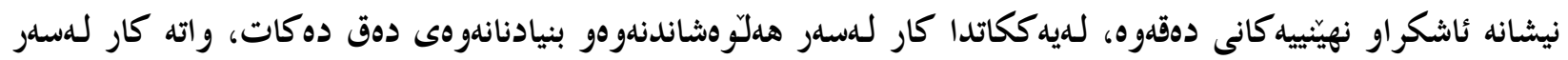

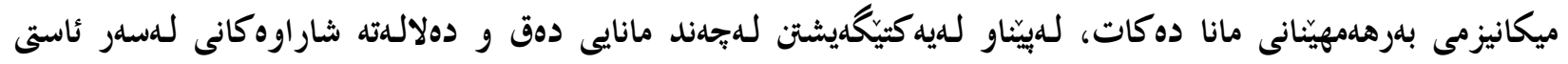

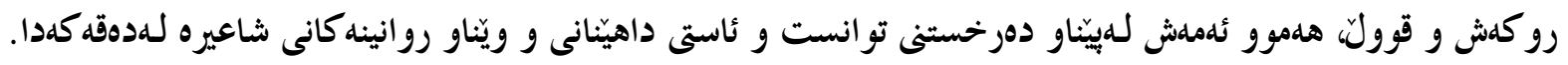

| . نيكوبخت و قاسم زاده،زهمينهای نمادين رنگ در شعر معاصر،نشريه دانشكده(ادبيات و علوم انسانى دانشگاه شهيد باهنر، كرمان، ز 11

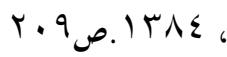

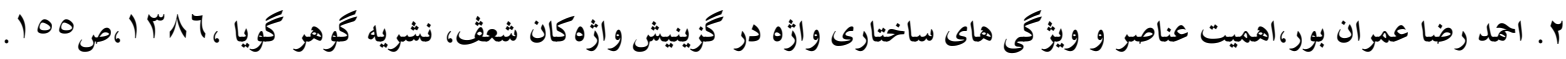




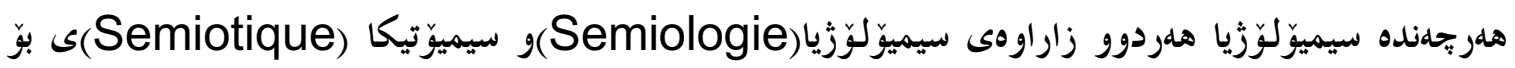

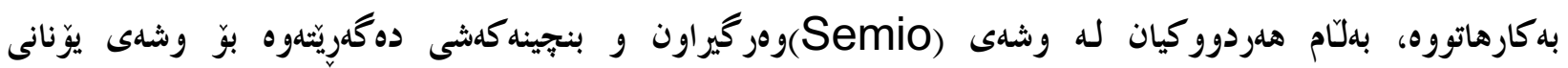
جياوازن، بهوهى له زاراوهى يه كهمدا (Suffixe) واتها (Semeion) (logie)

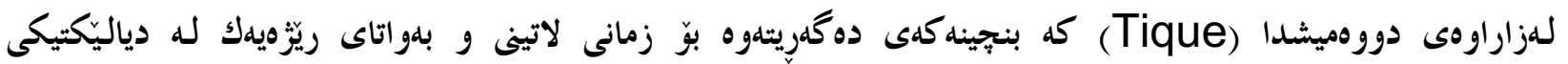

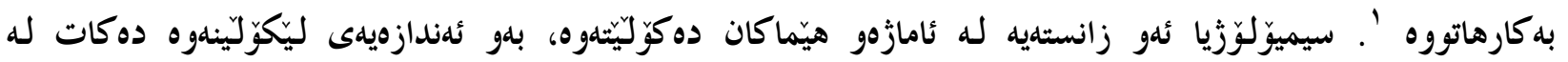

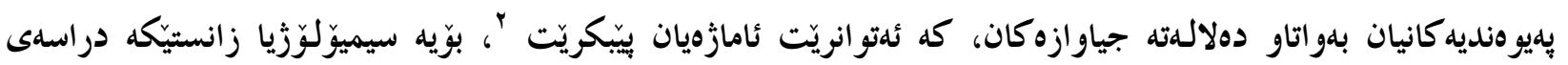

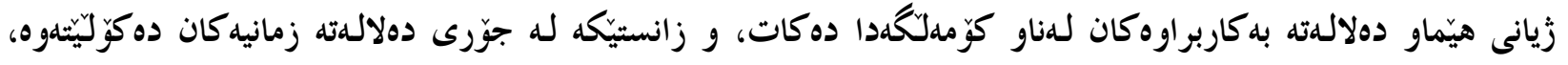

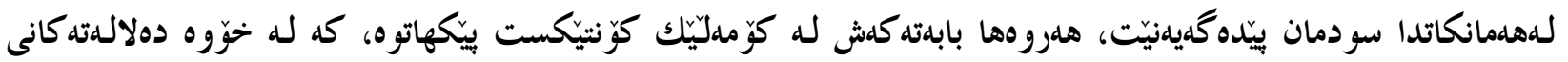

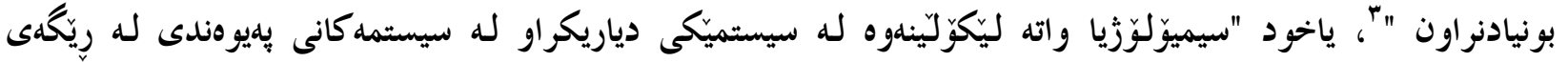

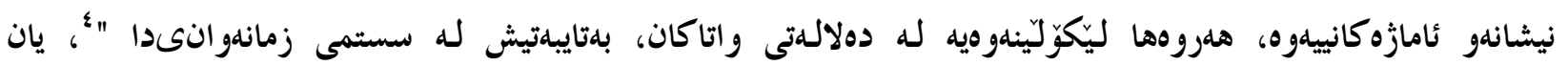

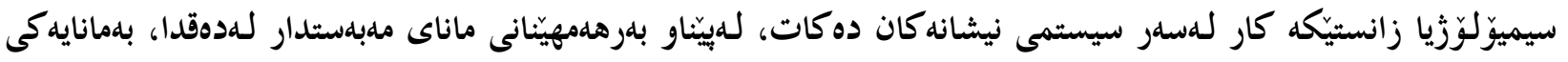

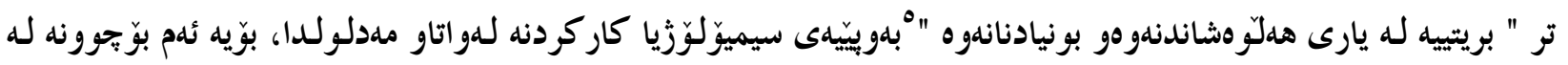

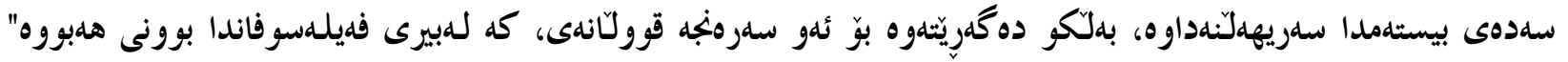

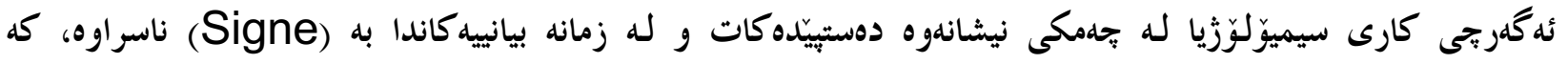

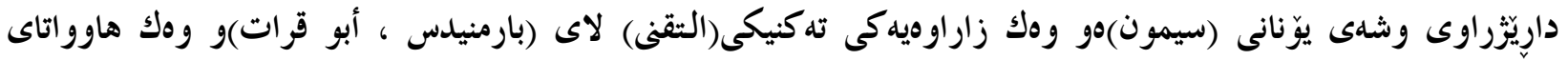

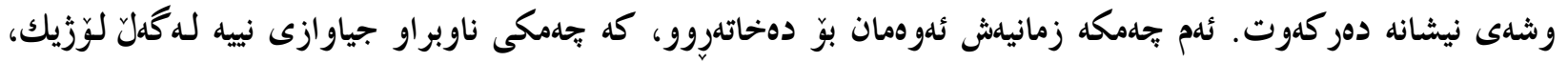

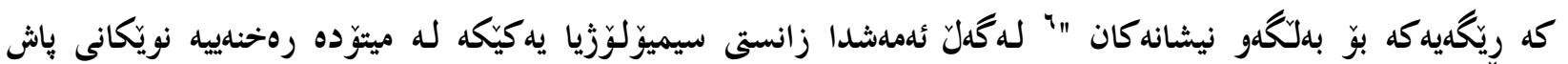

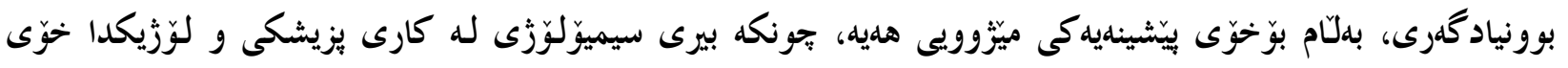
vناساندوه

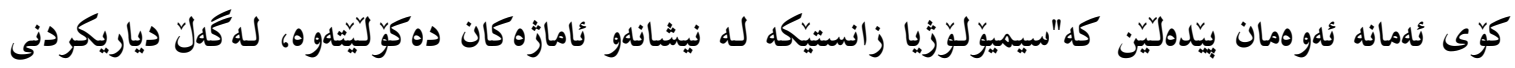

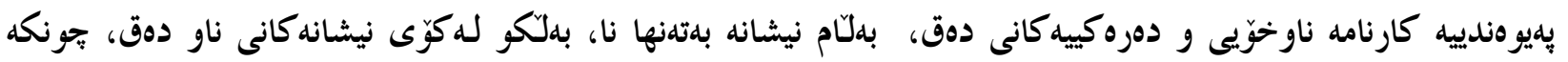

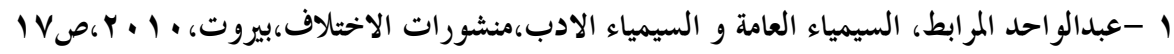

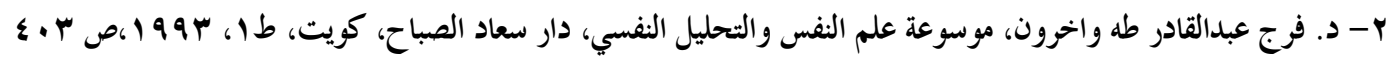

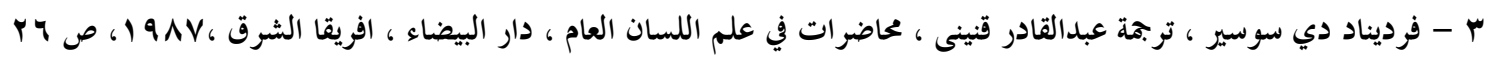

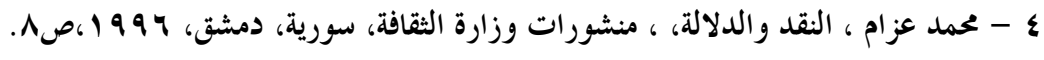

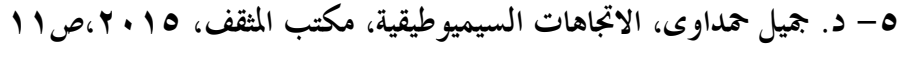

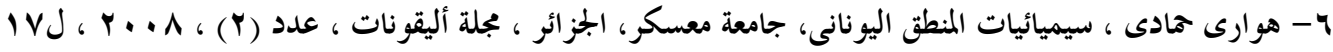

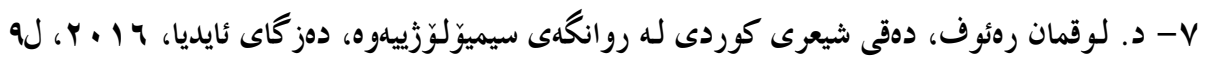




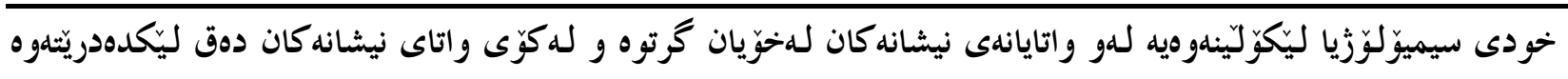

\section{كرنكى رهنگ لهدهقدا:}

رهنگ بريتييه لهسيفهتى تهنيّك و دهبيّنه ناسنامهو جياكارى للهنيّوان ئهوانى ديدا، بلييّى زانستى فيزيك" رهنگ

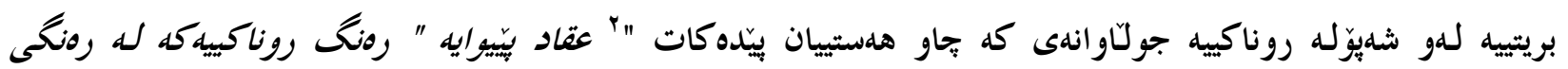

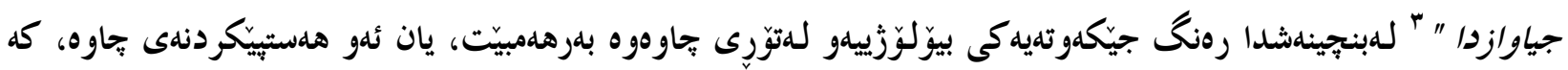

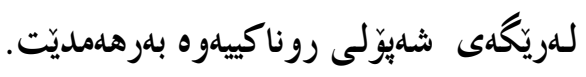

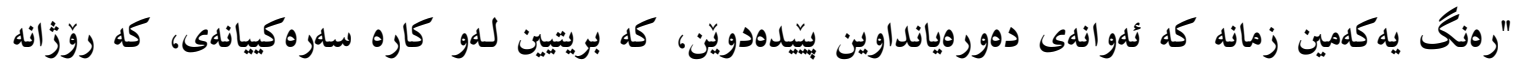

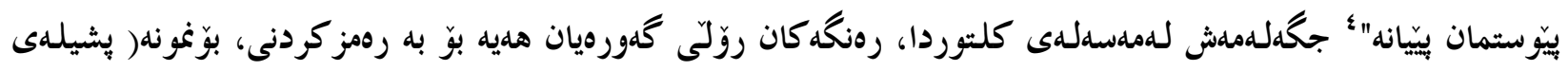

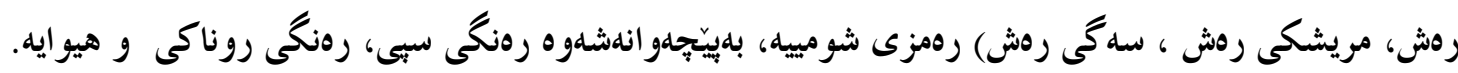

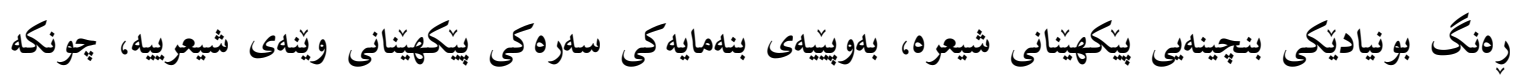

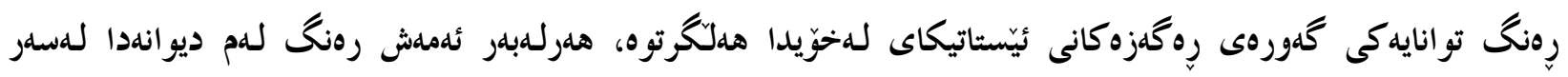

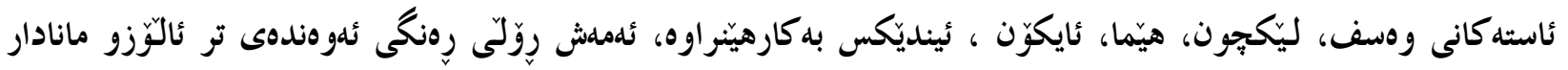
كردووهن.

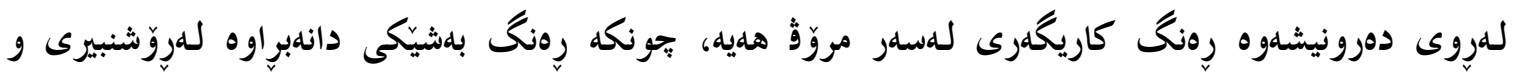

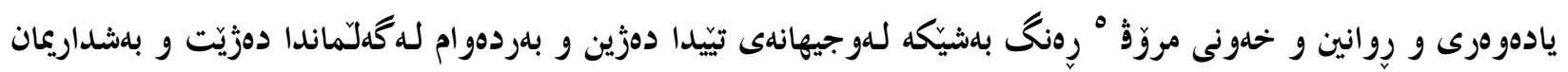
لـهُّلدا ده كات.

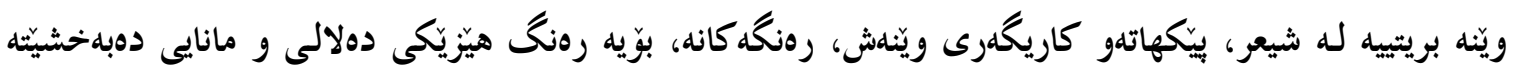

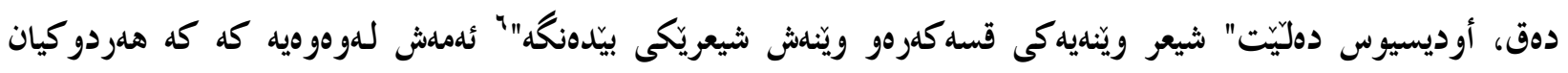

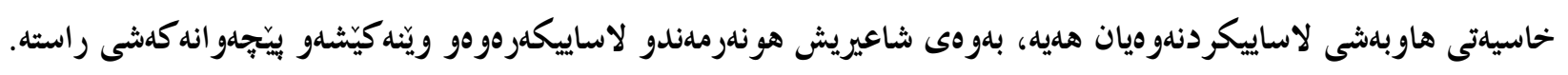

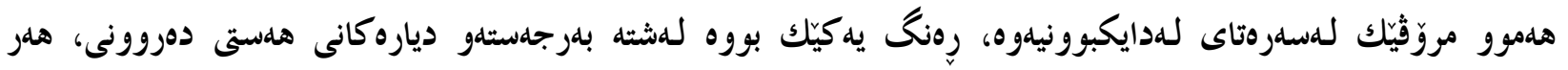

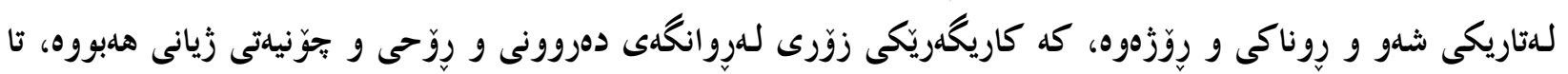

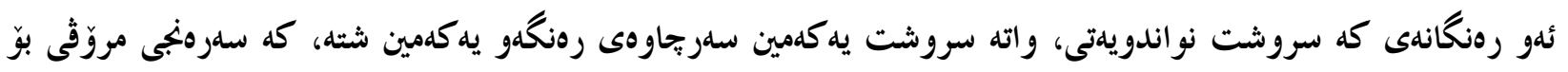

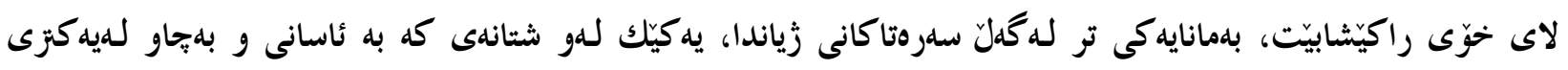

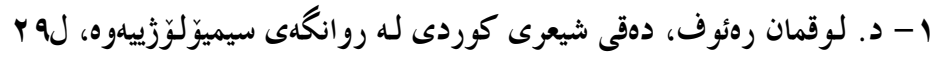

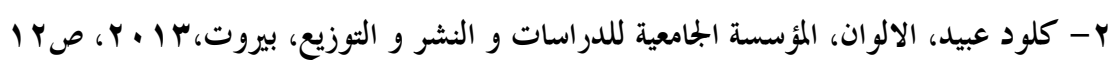
r

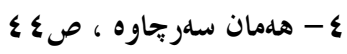

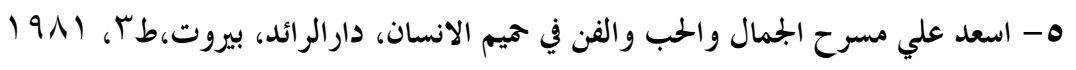

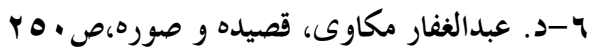




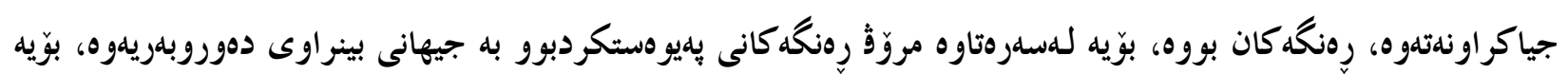

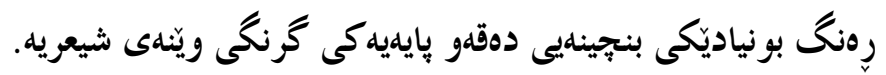

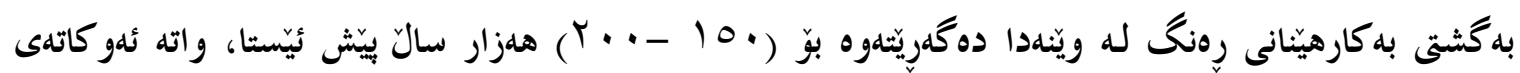

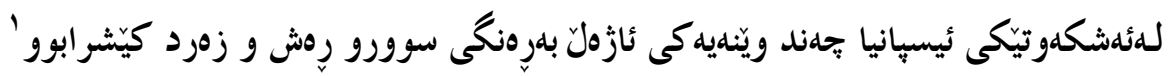

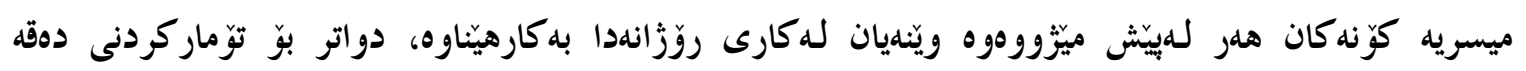

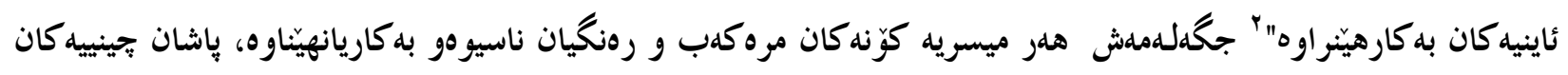

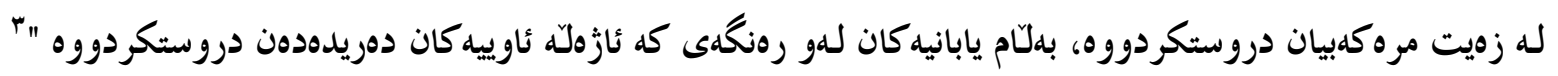

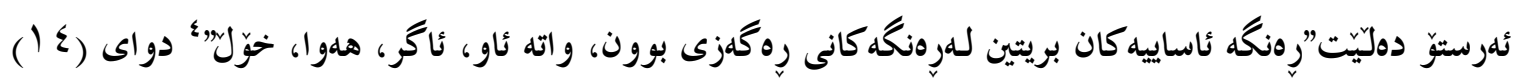

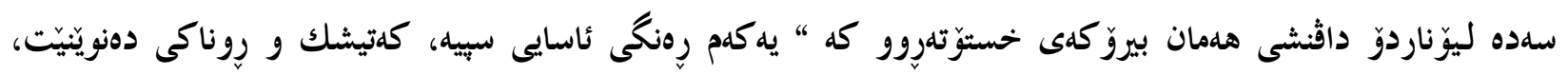

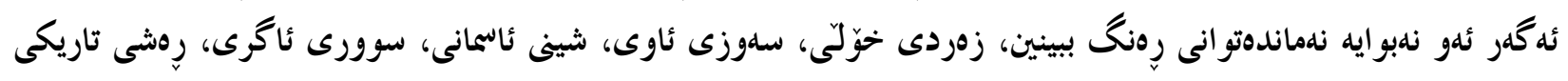

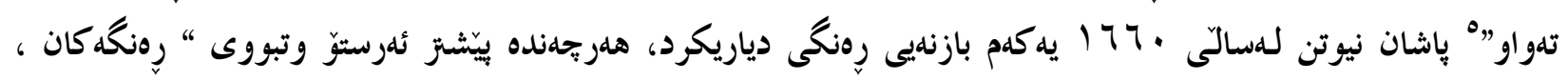

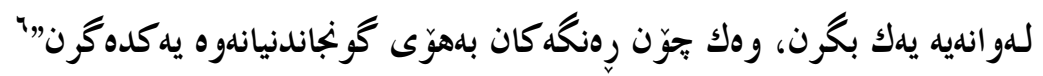

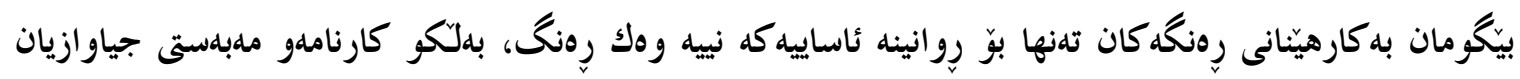

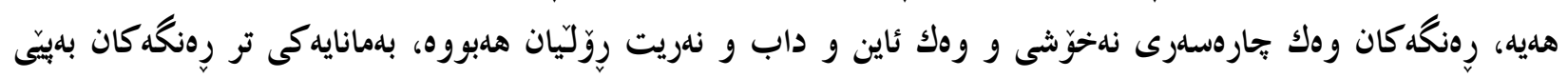

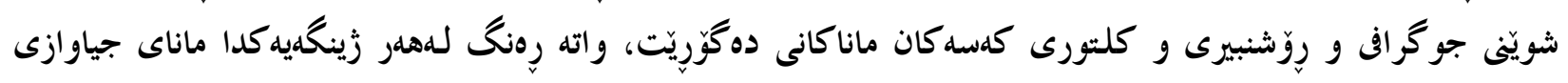

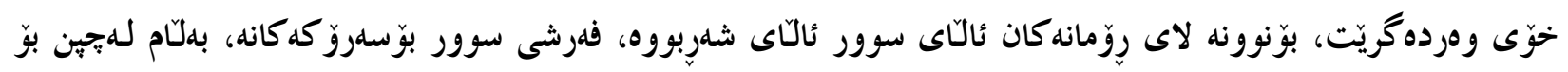

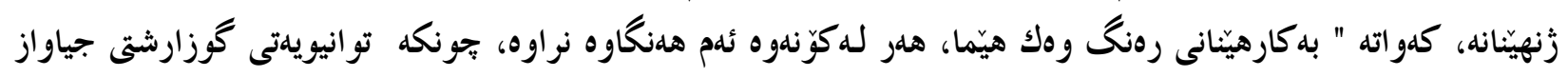

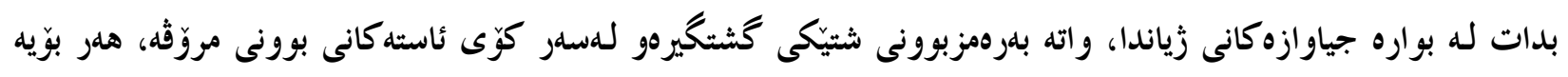

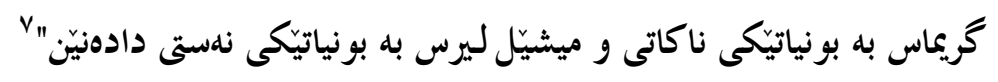

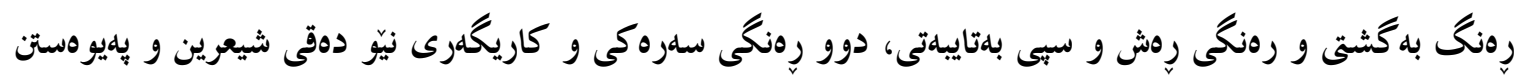

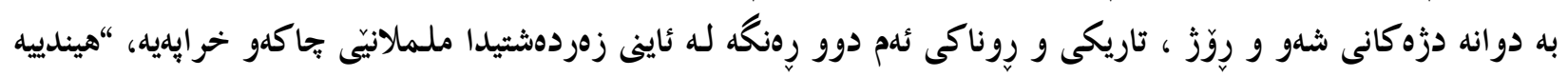

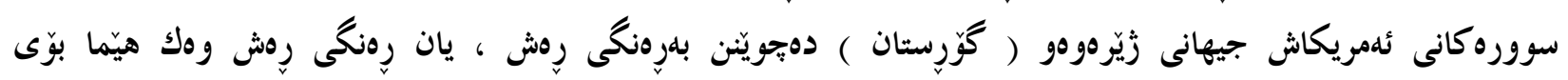

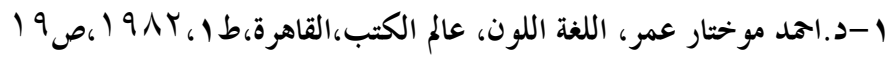

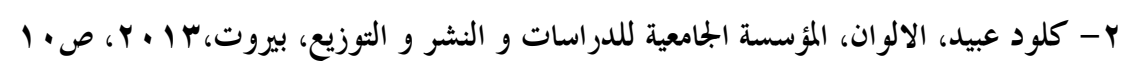

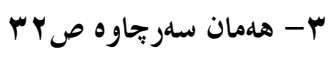

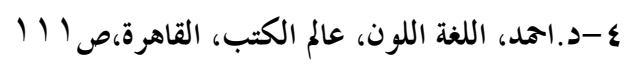

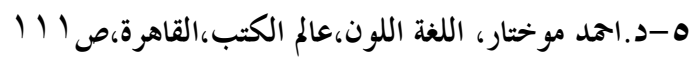

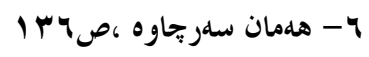

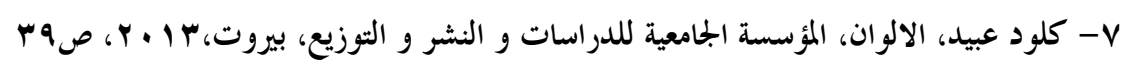




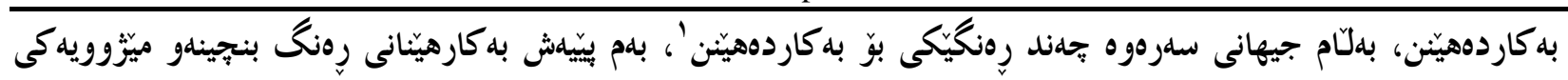
كوّنى هليه.

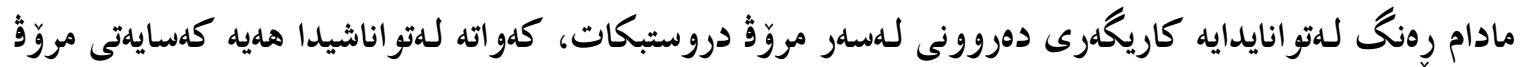

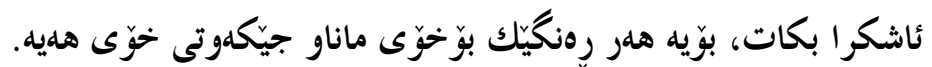

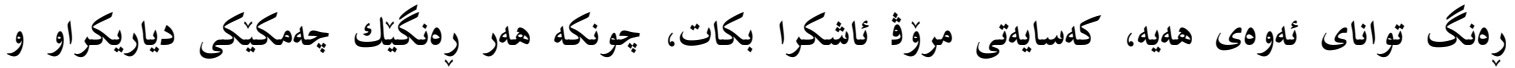

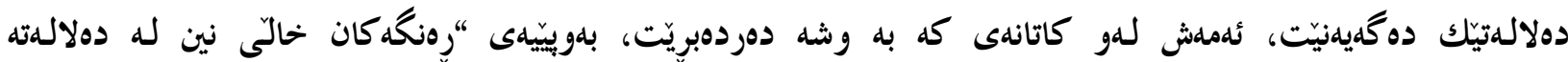

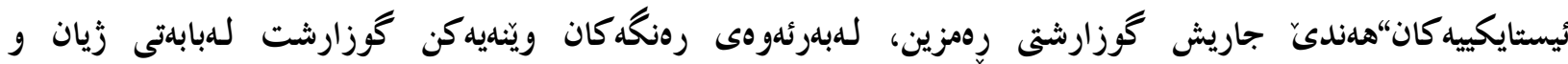

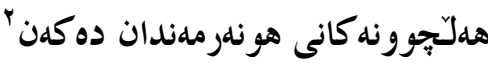

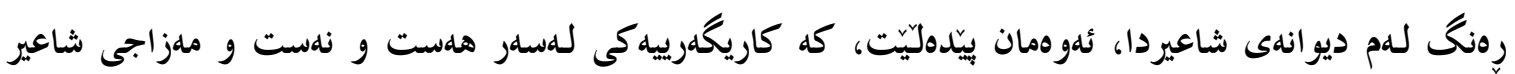

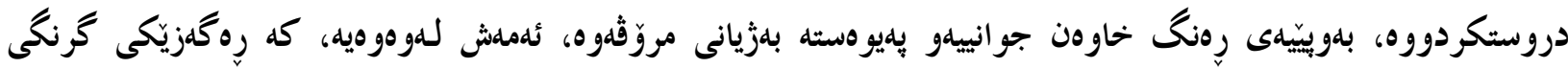

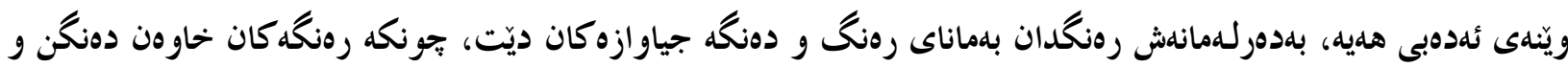

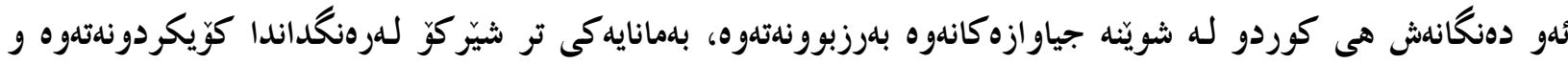

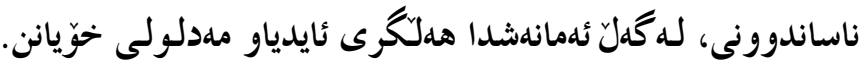

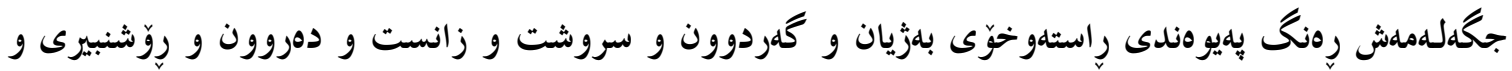

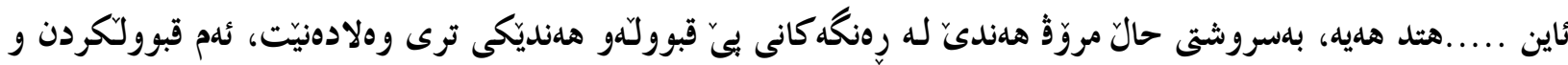

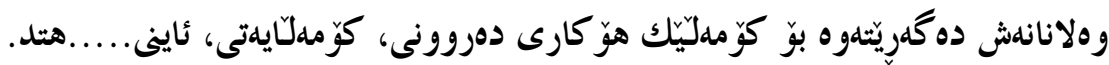

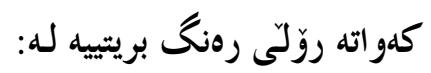

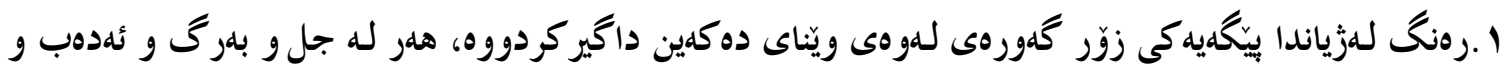

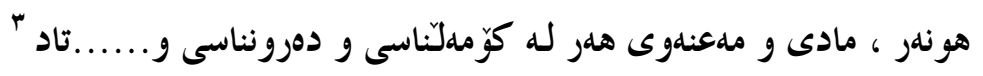

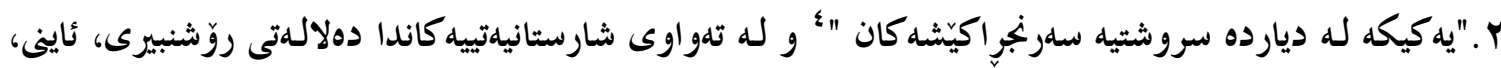

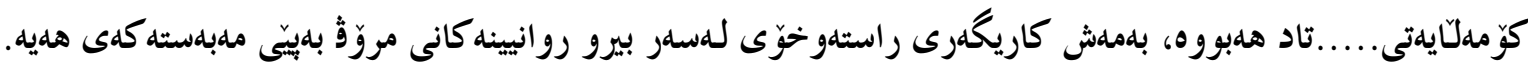

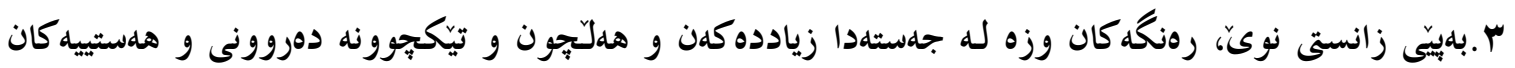

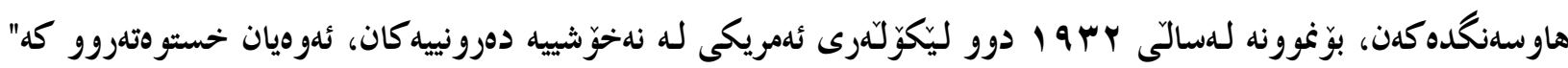

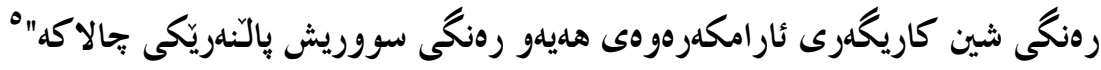

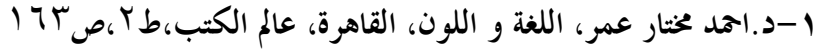

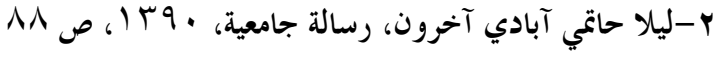

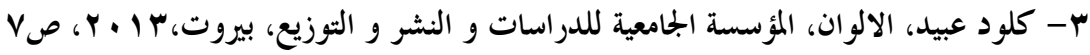

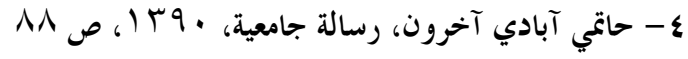

$$
\begin{aligned}
& \text { 0- هلمان سهر جاوه ، صצr }
\end{aligned}
$$

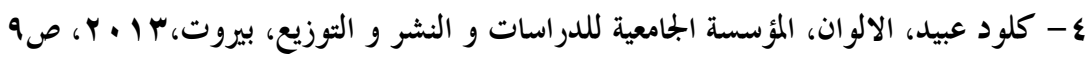




\section{دهلالدتى رِنگ له ديوانى رِنگداندا:}

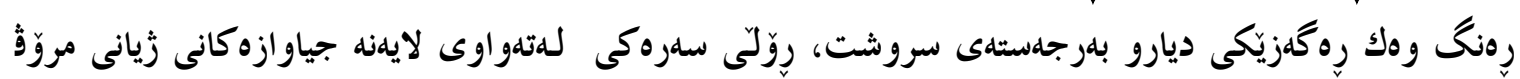

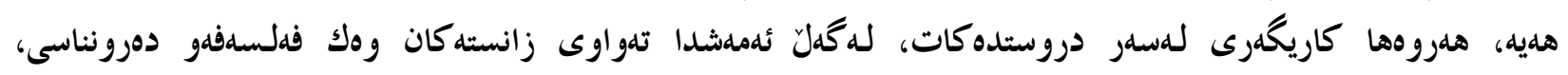

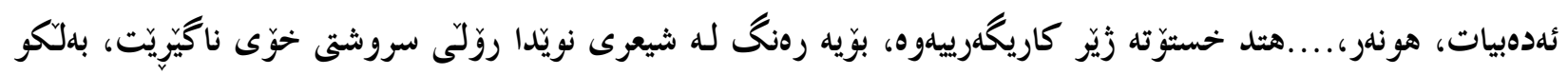

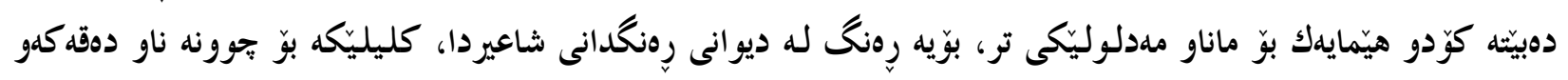

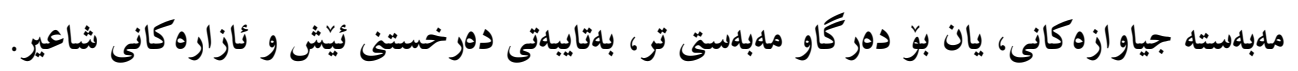

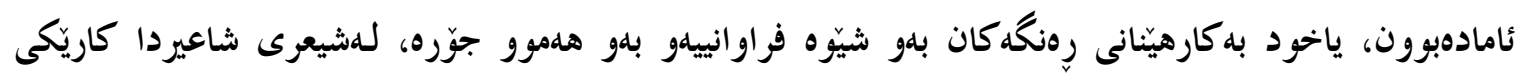

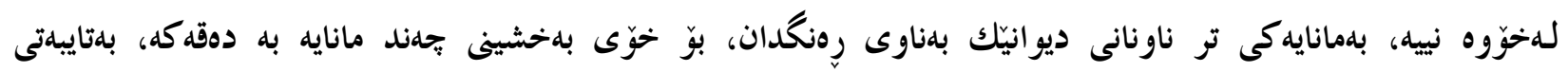

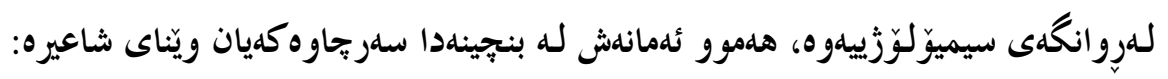

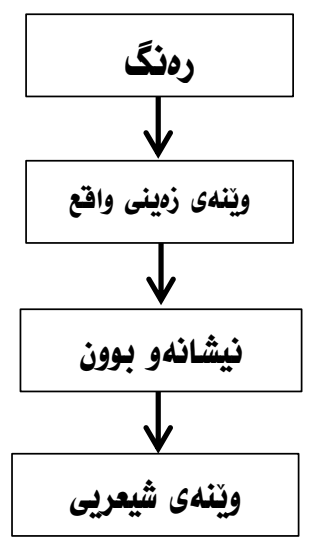

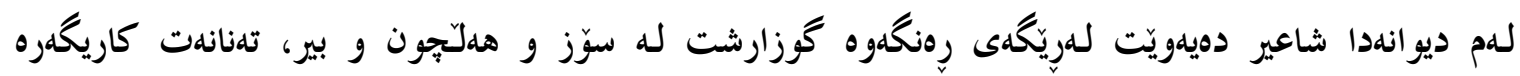

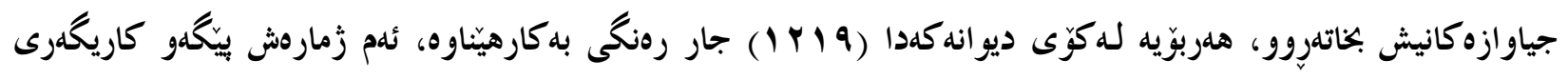
دهسهلمينيتيت.

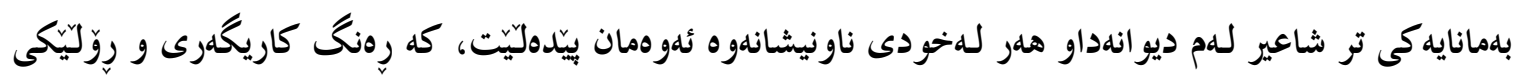

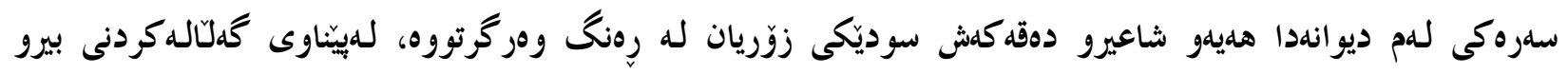

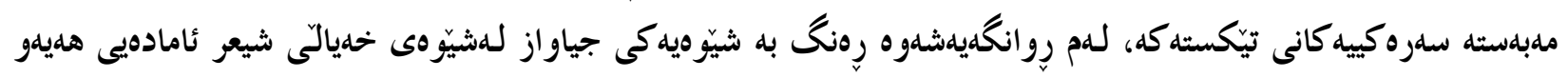

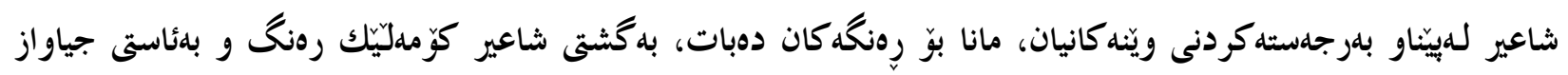

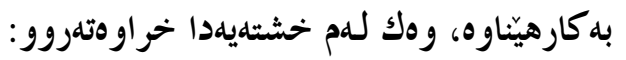

\begin{tabular}{|c|c|c|c|c|c|c|c|c|c|c|c|c|}
\hline 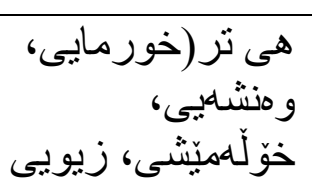 & موّر & ياهماهيى & ريرنكان & قاو هيى & ساموز & زهرد & سبیى & |رهش & سوور | & شين & ريرهن & \\
\hline TV & $r$ & 7 & $V$ & V & rT & rT & $r V$ & $\varepsilon$. & §1 & $\leqslant 0$ & 9.0 & \\
\hline
\end{tabular}




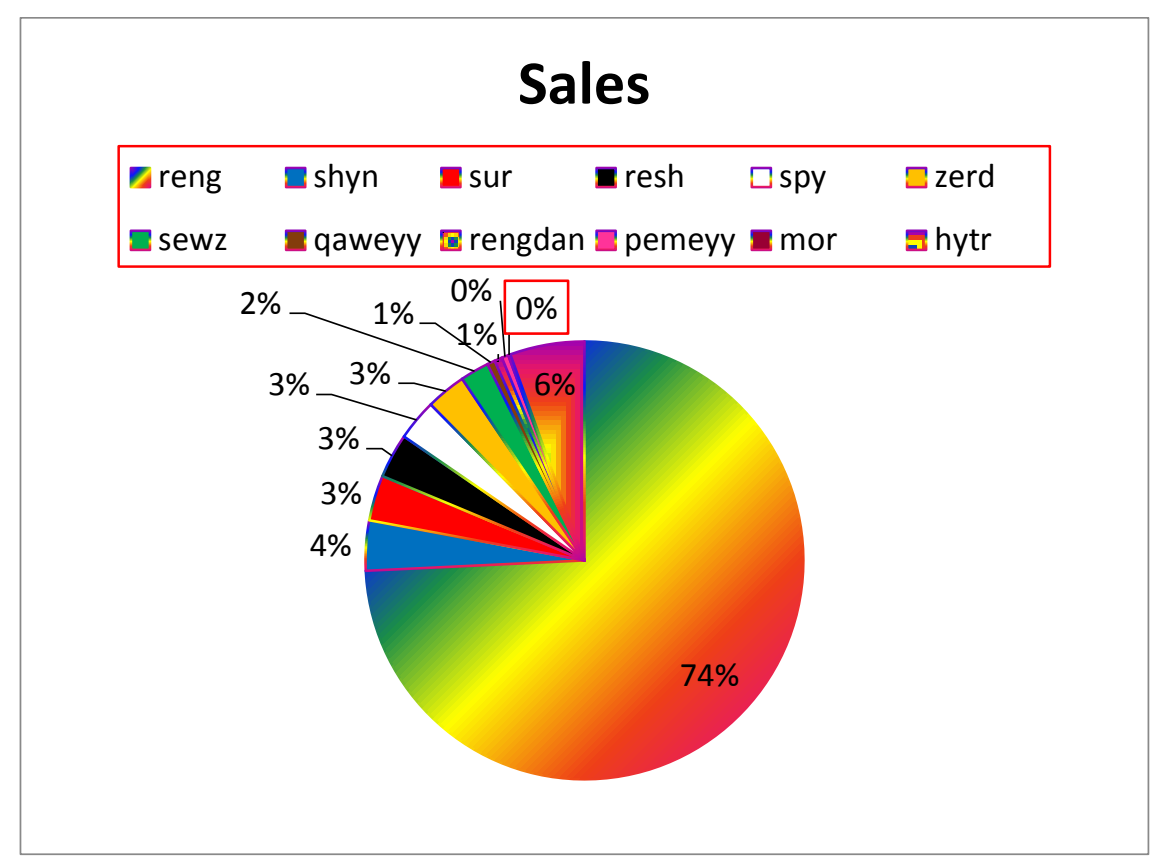

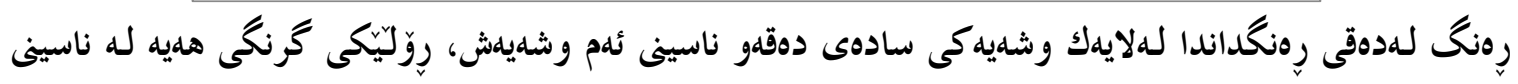

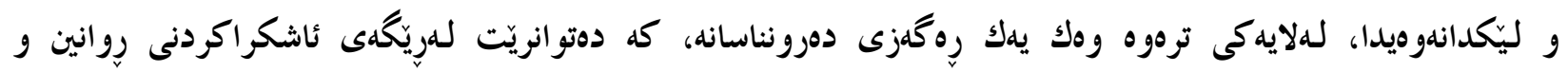

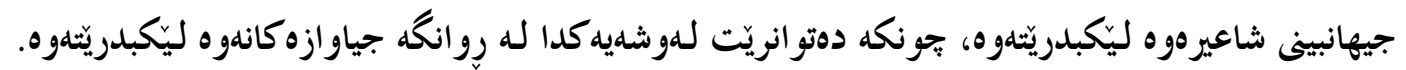

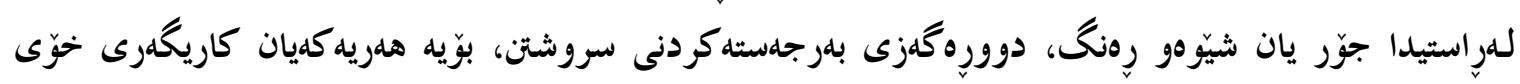
للهسهر دهروونى مروّة هديه، بوّنموونه: : 1

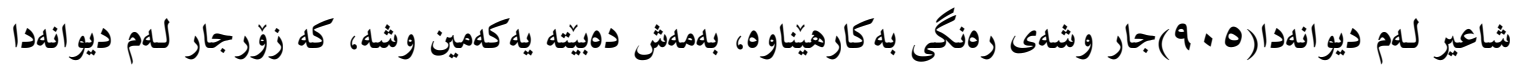

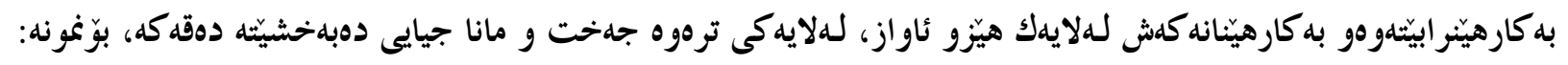
ا. وهك رهنگ لههdمانكاتيشدا هلستيارى و وردى شاعيرمان بيشاندهدات للهبهكارهينانى رهنگ له كارنامليهكى تر و لهناو تيّكستى شيعرييدا، وهك دهليّ:

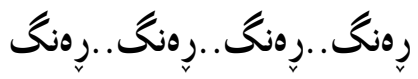

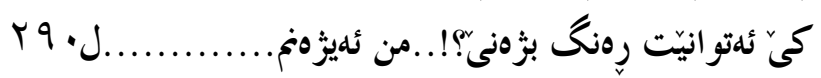

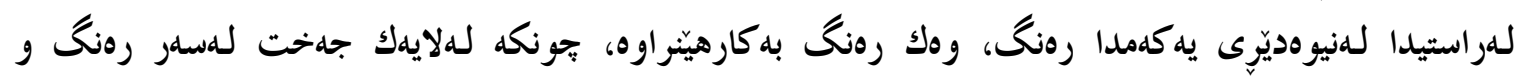

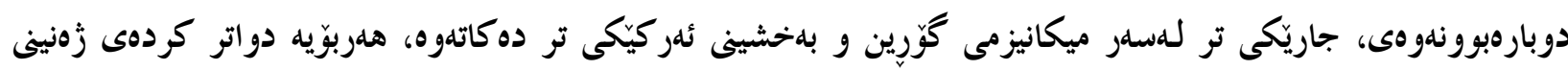

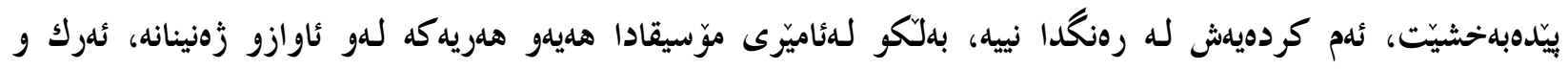


كارنامهى خوّيان هليه، بوّيه رهنگيش للممادييهتهوه بهرهو ئهرك و كارنامه دهبات، بوّيه ليّرهوه رهنگ بهرهو مهدلولبوون دهبات و زَهنينيش خوّى له جولَّهدا دهبينيّتهوه.

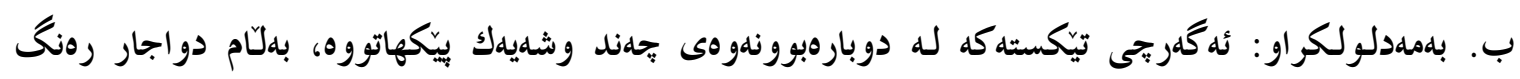

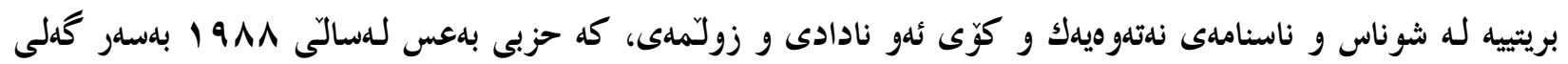

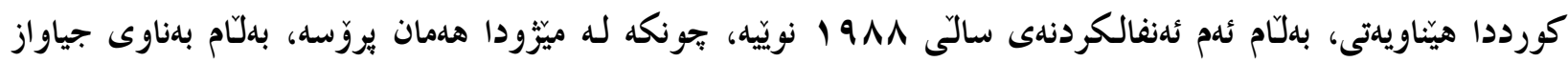

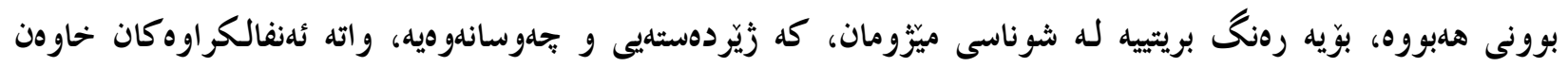

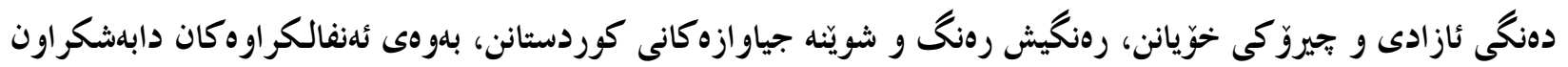

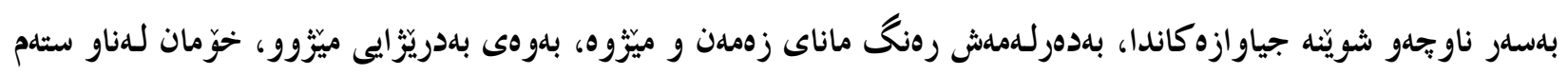
و كوشتن و جحهوسانهوهدا دهبينييهوه، وهك دهليّت

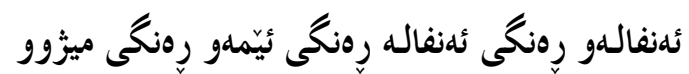

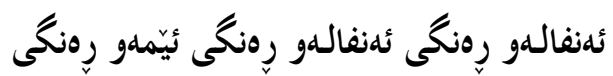

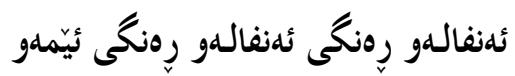

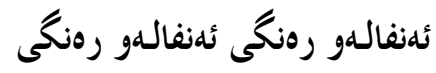
ئهنفالهو رِنكى ئهنفال

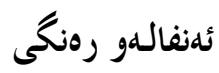
ئهنفال....................

جكهلهمهش رهنگ بريتييه له دهنگ و رهنگ و ناسنامه جياو ازهكان، بريتييه للهو سيماو هاوارى ئازادييانهى، كه

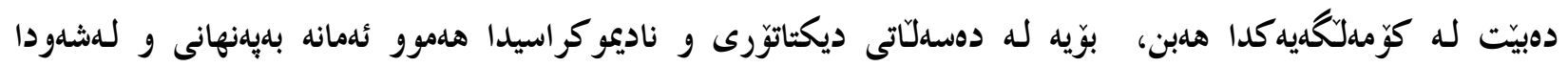

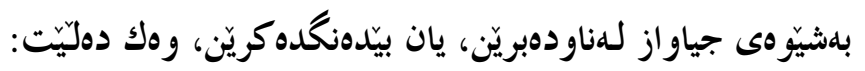

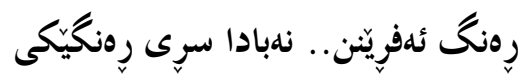
تازهى لابعَ و بيدر كينى

رهنگ كهر ئه كهن....نه بادا گُويّى

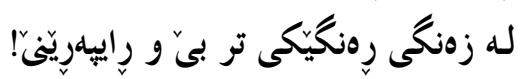

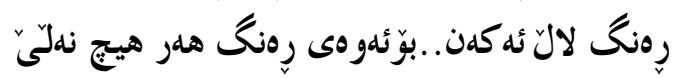
بلهردهو اميش هلر له شهودا رهنگ ئه كوزن

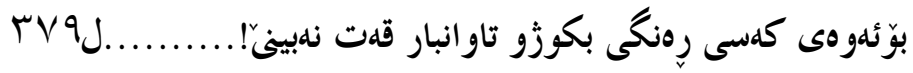

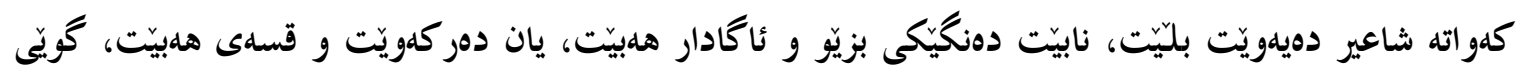




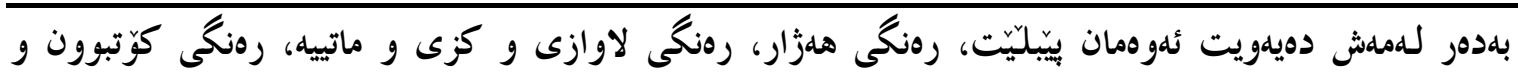

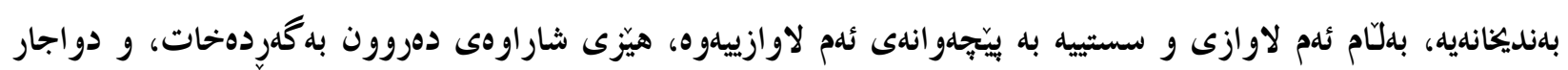

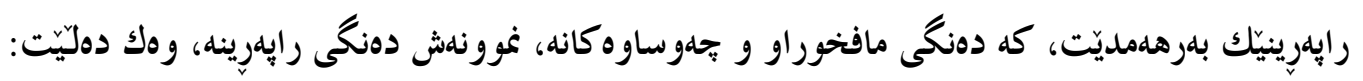

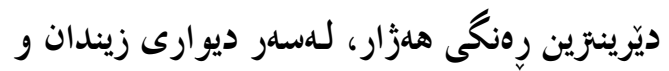

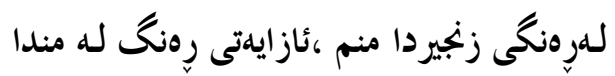

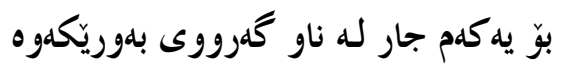

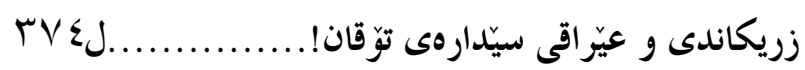

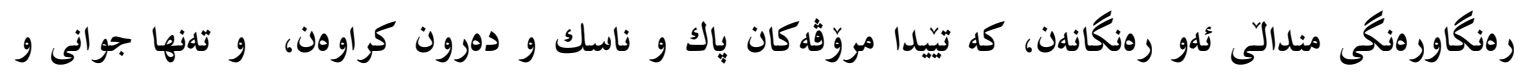

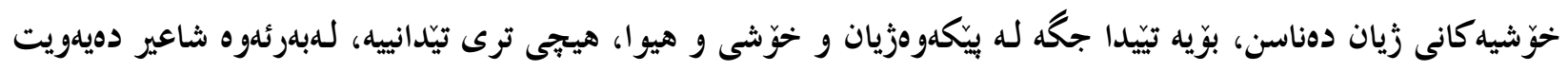

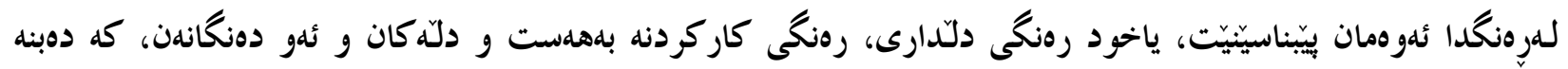

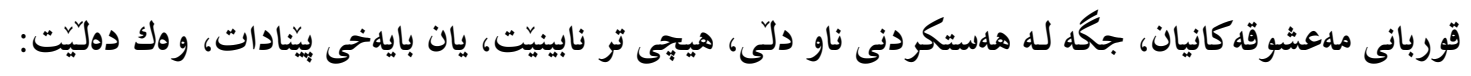

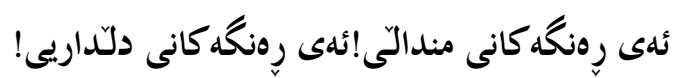

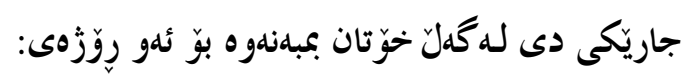

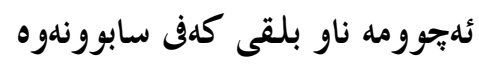

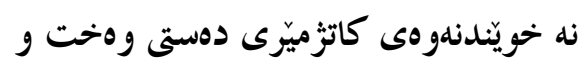

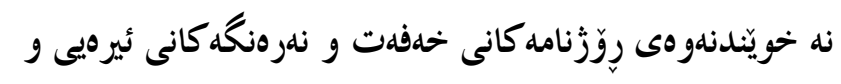

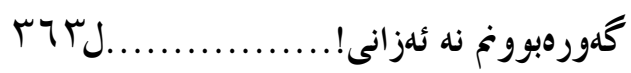

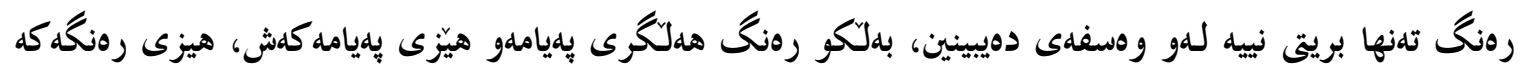

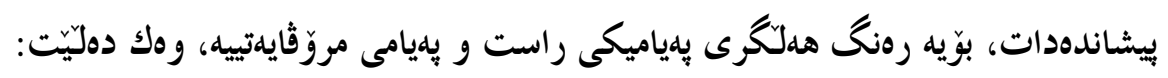

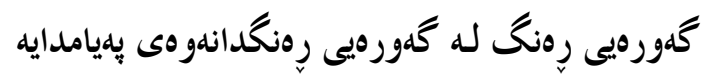

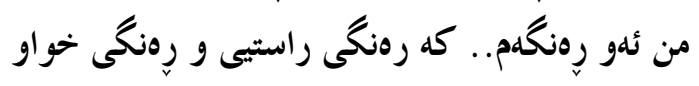

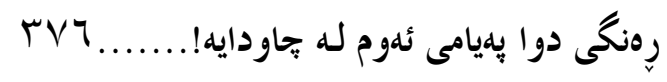

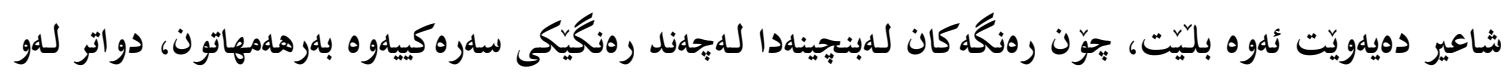

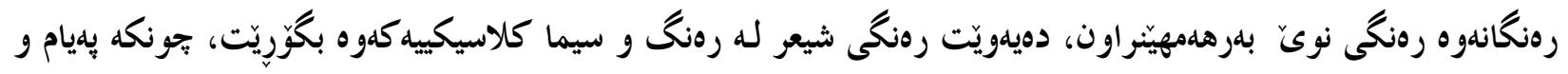

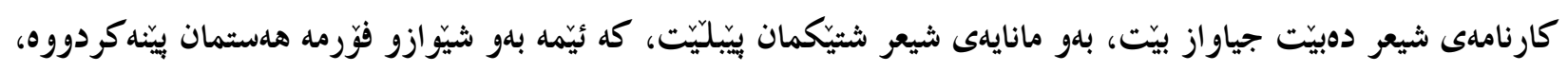
وهك دهليّت:

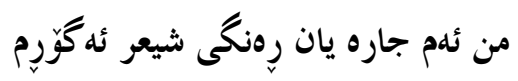

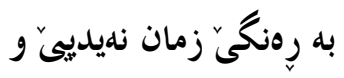

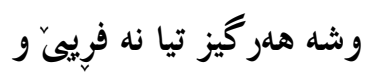




$$
\text { كاغهز خهوى بيّوه نهبينيى }
$$

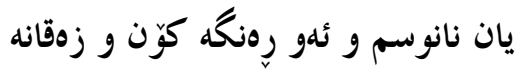

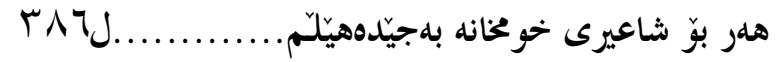

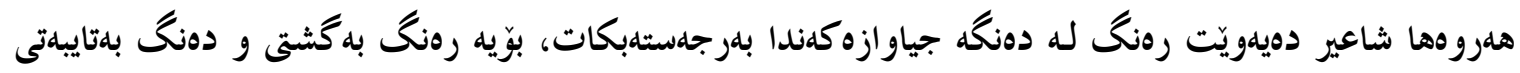

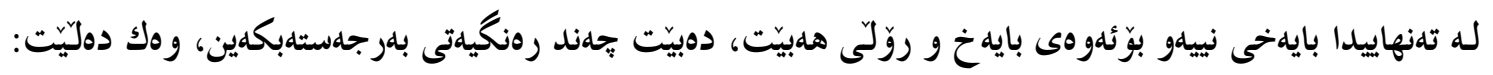

$$
\begin{aligned}
& \text { لـهو دوّلَّدا }
\end{aligned}
$$

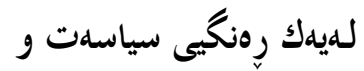

$$
\begin{aligned}
& \text { لهيهك رِنكيى كتيّبه كان ياخيى ئهبورين }
\end{aligned}
$$

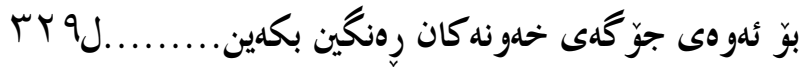

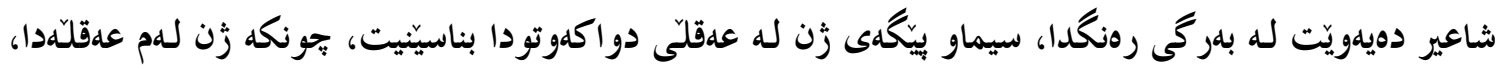

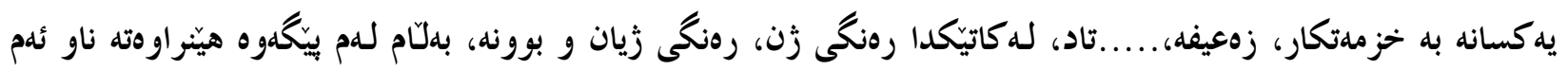
بهراويَّخستنهوه، وهك دهليّت

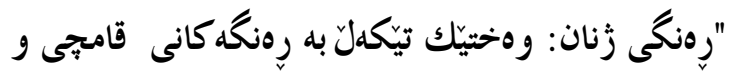

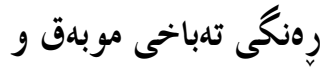

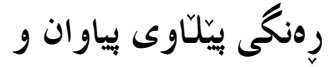

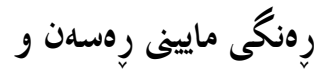

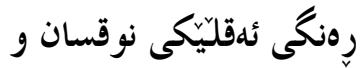

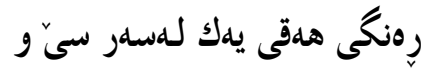

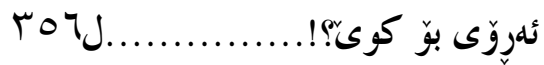

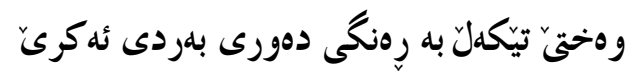

هلروهها دهنكى كردوهته سيماو شوناسى ئهوانهى، كه ناتوانن بوونيلهى خَّيان بسهلميّنن، بوّيه نئهانه هدر بلهو

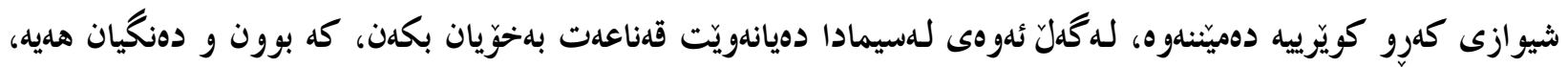

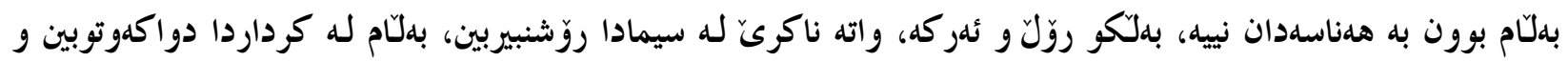

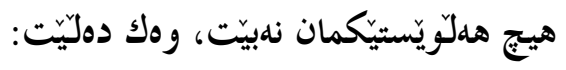

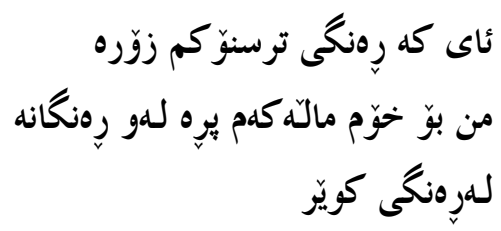




$$
\begin{aligned}
& \text { له رهنكى لالَ }
\end{aligned}
$$

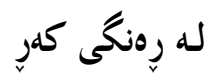

$$
\begin{aligned}
& \text { ئاى كه رهنكى ترسنوّ كم زوَره }
\end{aligned}
$$

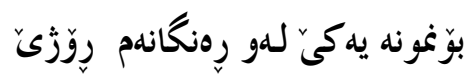

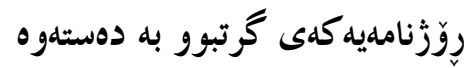

$$
\begin{aligned}
& \text { رهش و سيى ئهخويَندهوه } \\
& \text { روّرَّنامه ناوى(رِاستى) بور } \\
& \text { دوو هdنگاو للهو لاى رهنگمهوه }
\end{aligned}
$$

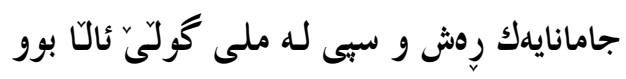

$$
\begin{aligned}
& \text { رهنگم دهنتى له رِوَّزنامه بهرنهدا } \\
& \text { ئهو هلر راستى ئهخويَندهوهو روني }
\end{aligned}
$$

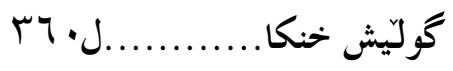

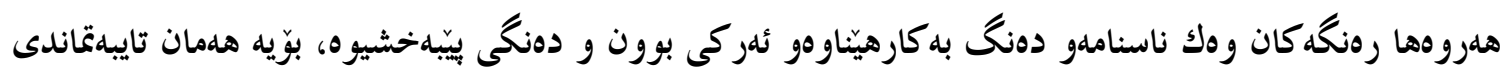

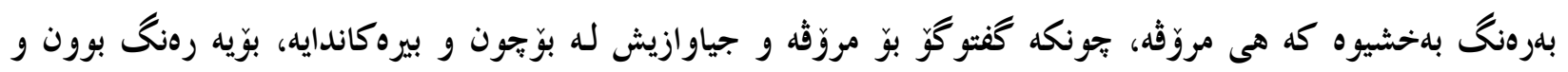
شوناسى ئهم رونكُانهيه، وهك دولّيتا:

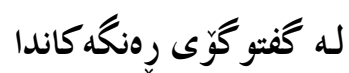

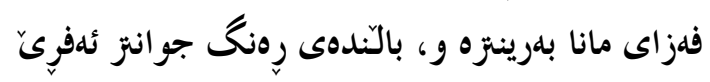

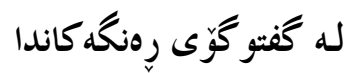

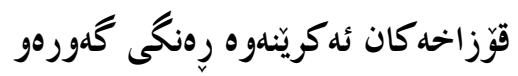
رهنكى بجِووك للهسهر يهك ميّز كوّئهبنهوه

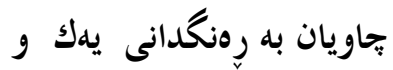

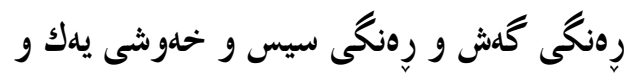

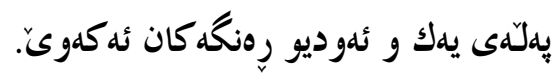

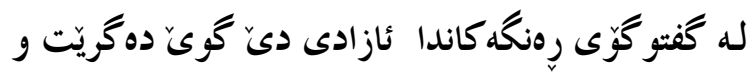

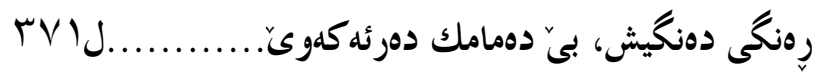

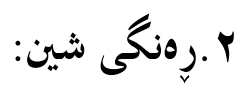

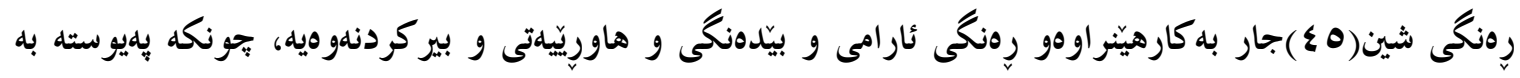

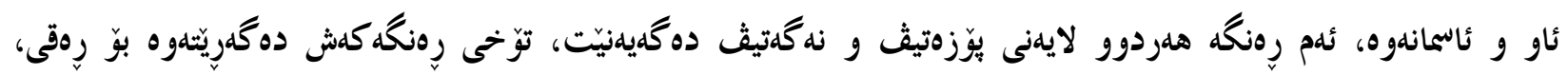




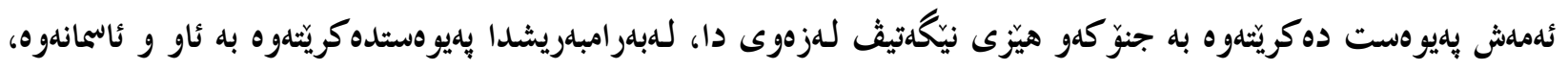

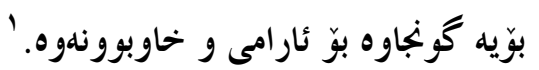

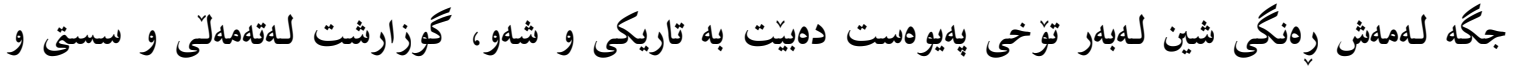
بيّدهنكى و حلهو انهوه ده كات

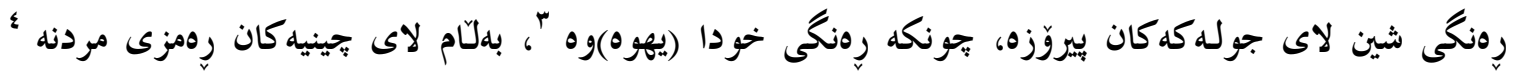

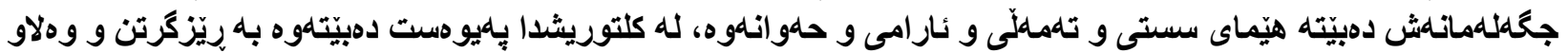

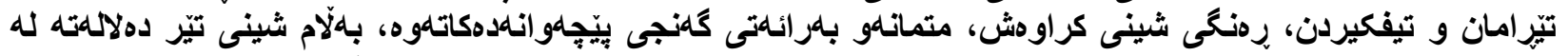

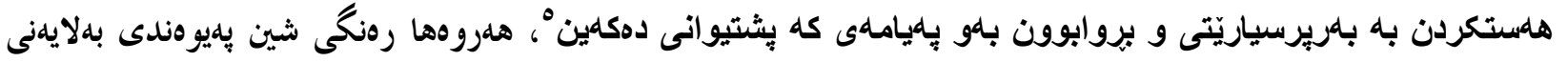

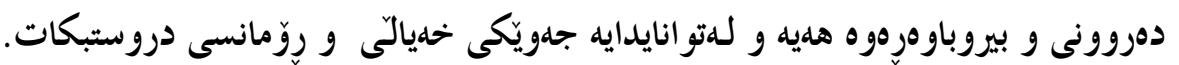

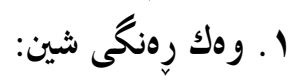

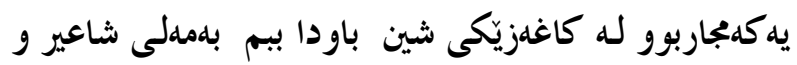

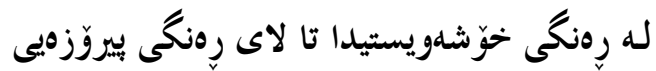

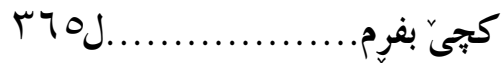

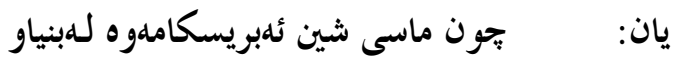

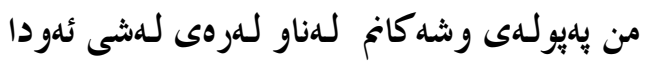

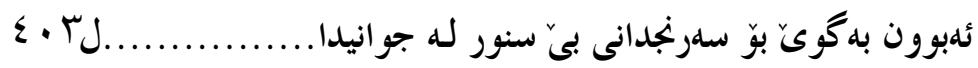

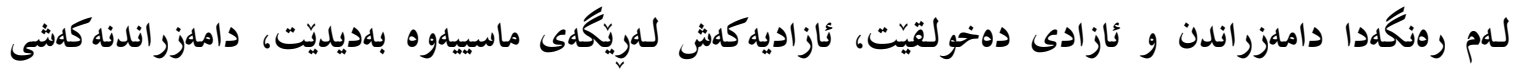
خوّى لله باكر اوندى و اقيعى ميّزوووى كورددا دهبينيّنهوه.

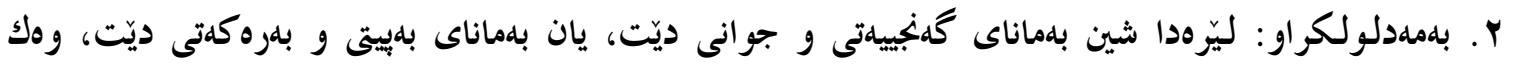

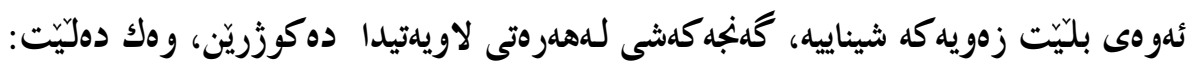
له شاخ بوايه ئليان كردين بله(شين) يَكى شيْت و شهيداى ميّالاقليى له دهست بوايه، ئليان كردين، به زهرديّكى حهيهساو ................ 


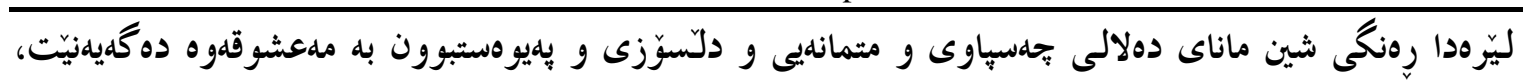
جكُلهمهلش دهليّت:

ئلهو شينانهى لله قهراخ شار لاشه كانيان دوّزرايهوه

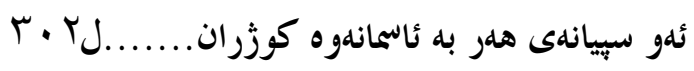

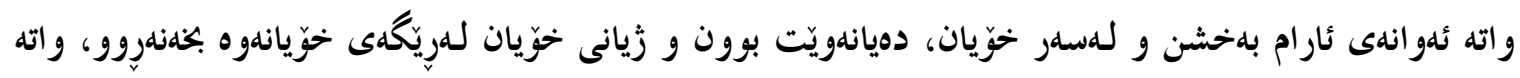

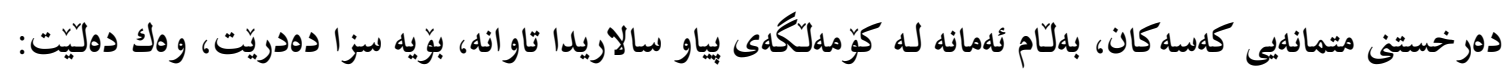

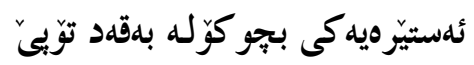
له لاى (شين) هوه هاتبوو

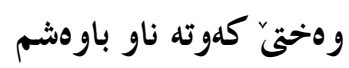

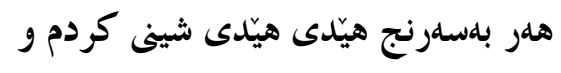
لمهو ساتهوه سامالَ جاومهلو زهرياش لهشم.........

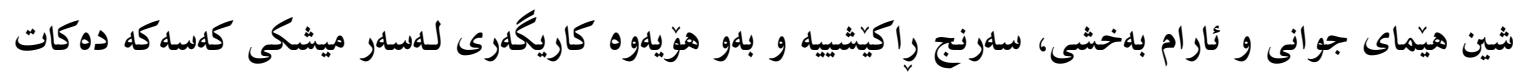

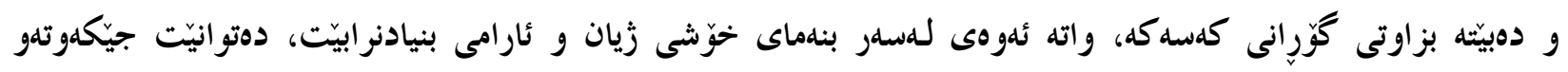

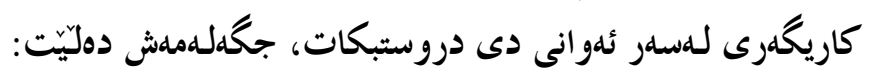
نهيّنى شين ئه گيّرِنهوه.

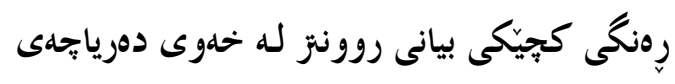

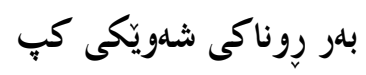

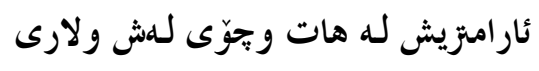

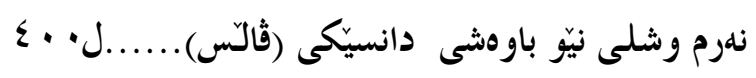

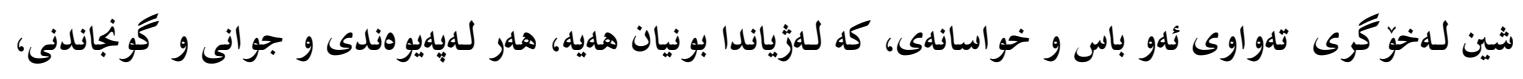

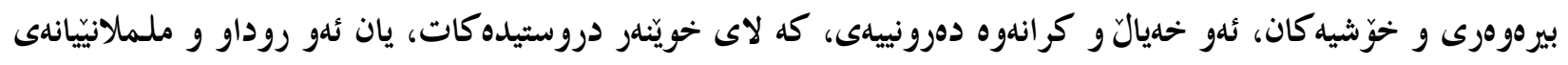

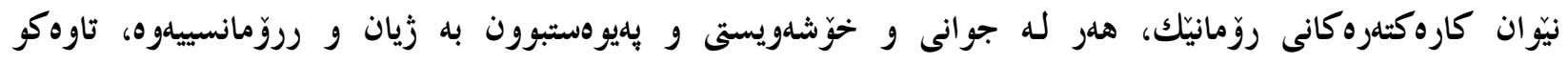

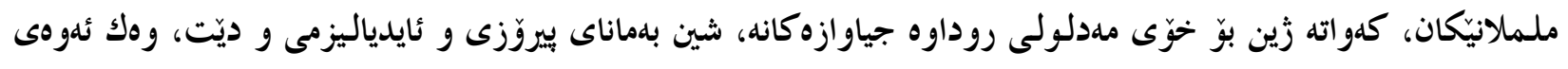

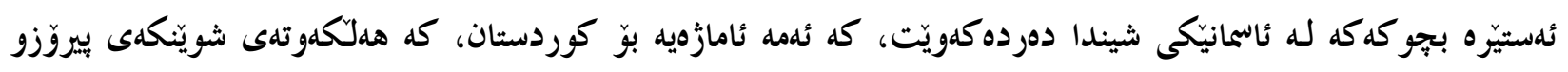
نمونهييه، وهك دهليّت:

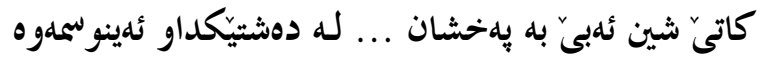

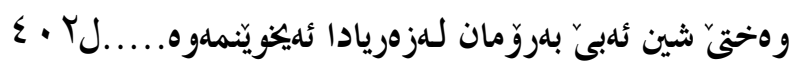




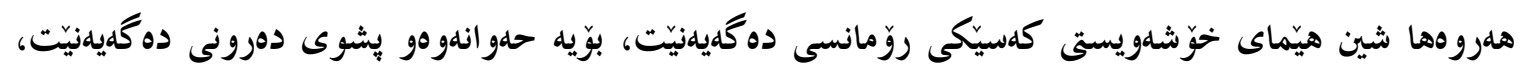
وهك دهليّت:

$$
\begin{aligned}
& \text { شهويّك شين له باخلَّماندا نوست، شين بردمى و دوور بردمى و }
\end{aligned}
$$

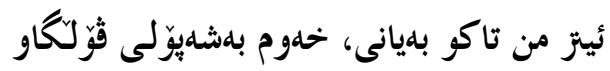

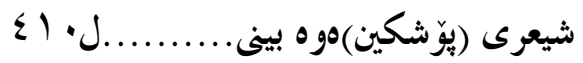

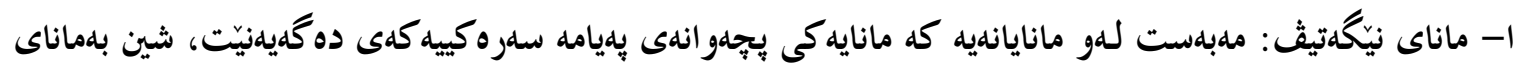

$$
\begin{aligned}
& \text { سهختى و كيّشه ديّت، وهك دولّيتّ: }
\end{aligned}
$$

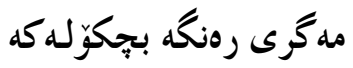$$
\text { توَ لله ماناى ئهم سهفهره شينه ناكَى }
$$

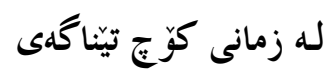

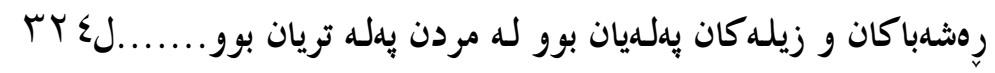

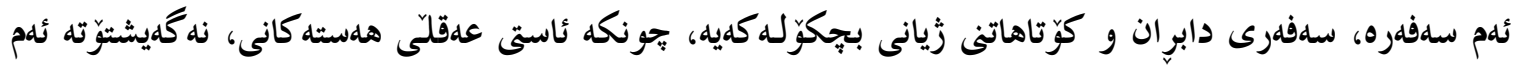

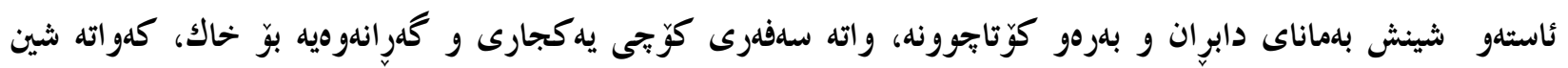

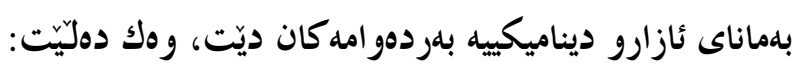

$$
\begin{aligned}
& \text { من للهبيرمه } \\
& \text { سوور ئليويست باران سووربكات } \\
& \text { زهرد ئليويست ئاسمان زهرد بكات و لهورئ } \\
& \text { سلوزيش ئلى ويست خويّن سلوز بيّت }
\end{aligned}
$$

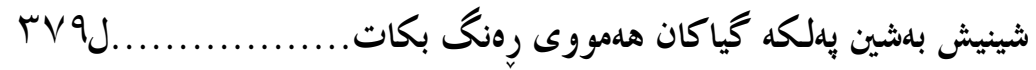

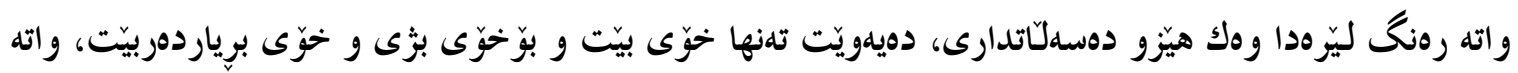

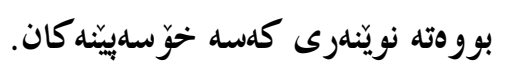

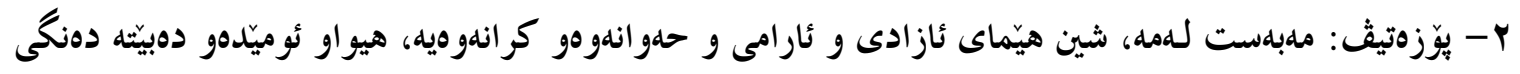

$$
\begin{aligned}
& \text { ئازادى و كُّ كهرهوهى دهنكُ كان، وهك دهلِّتَ: } \\
& \text { وهرزى دهسهلّاتى سووربوو } \\
& \text { دنيابوو بوو به سوورستان } \\
& \text { شينيّك ويستى بلشهقامى سووردا برواو }
\end{aligned}
$$

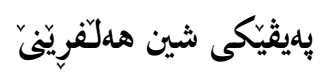

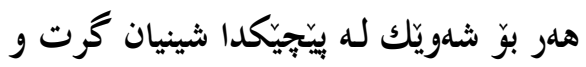

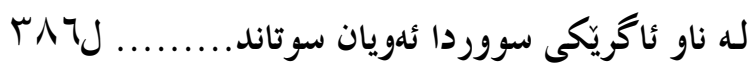

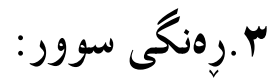




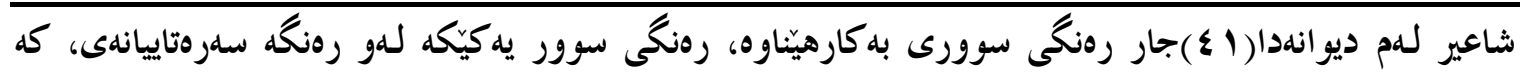

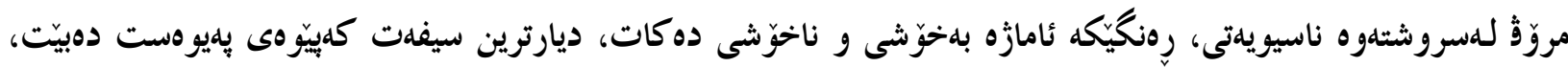

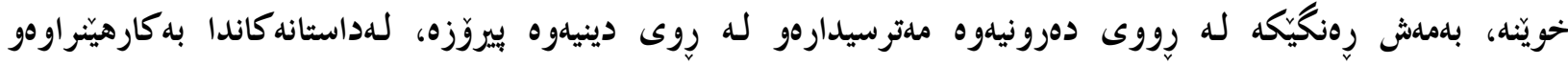

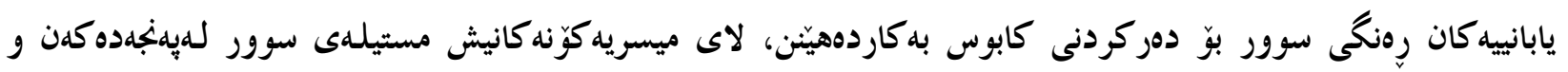

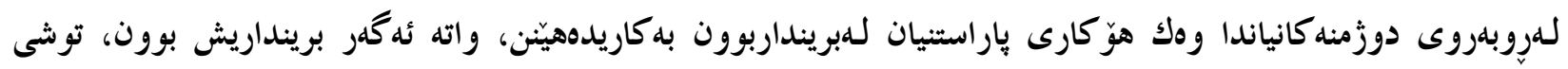

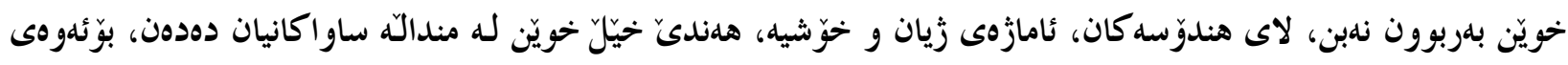

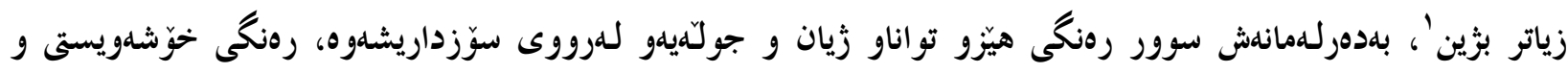

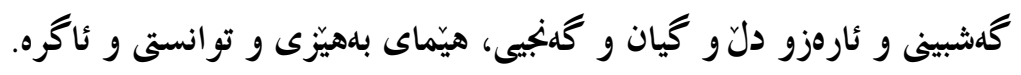

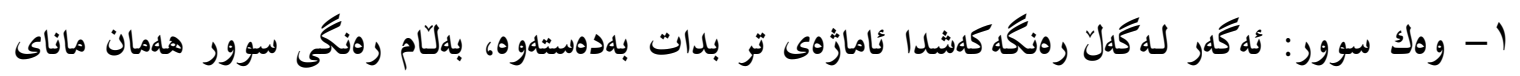

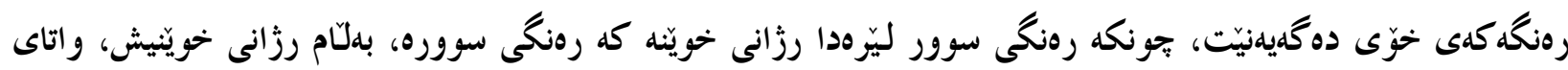

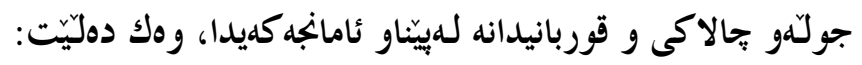

$$
\text { رهنكى سوورى }
$$

ra人

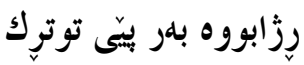

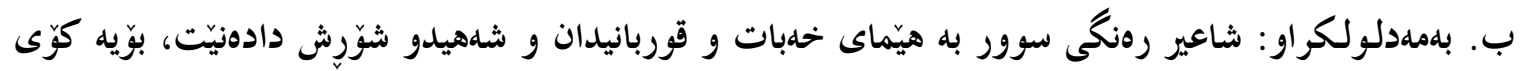

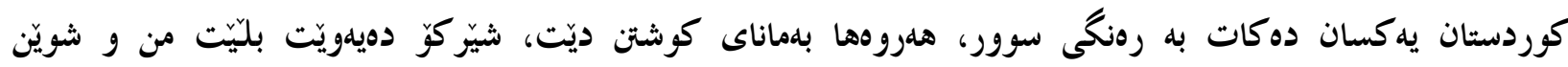

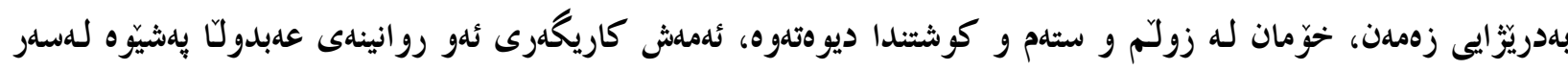

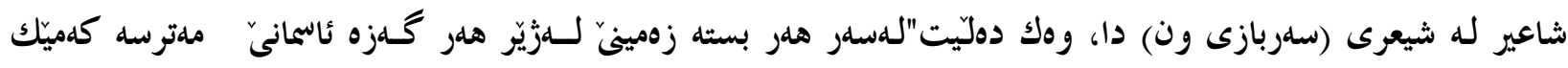

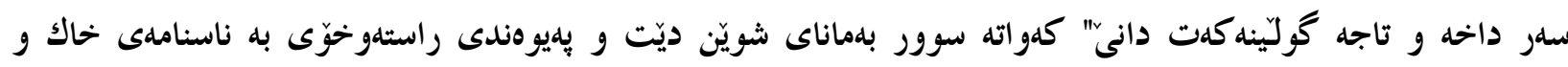

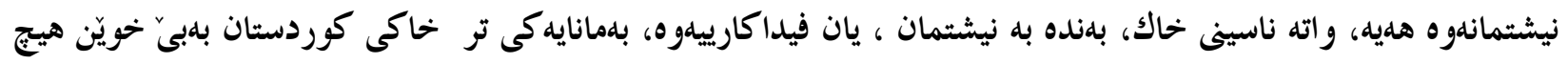
مانايهكى نييه، وهك دولَّيّت"

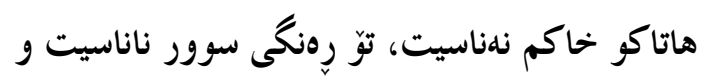

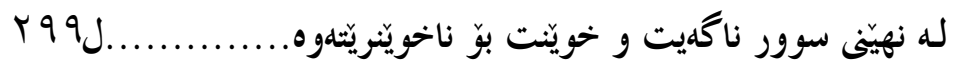

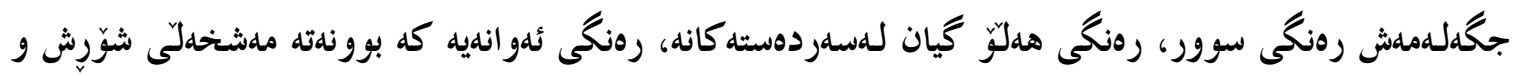

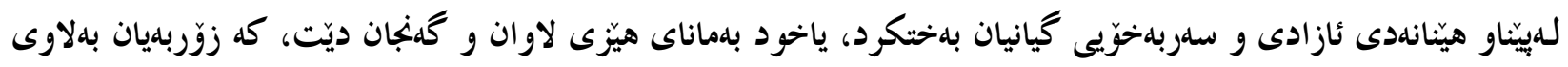

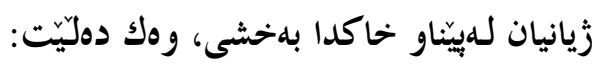

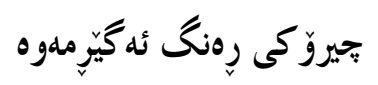

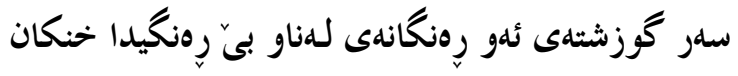

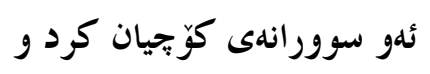

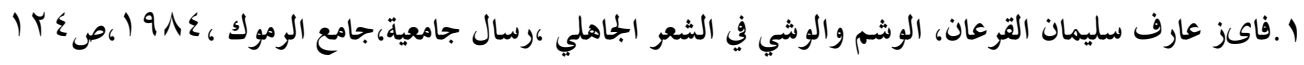




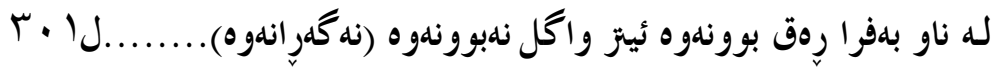

$$
\begin{aligned}
& \text { ياخود دهليّت: لاى (سوور)ووه زاميّك هاتبوو كرمانجى } \\
& \text { باريكهله جوون خهيالَى بهلالوك و و بهبريسكه } \\
& \text { جون ملر اقى رهنكى زالّو }
\end{aligned}
$$

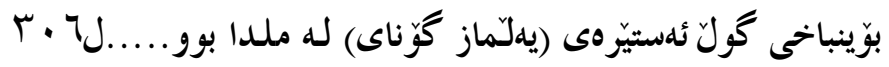

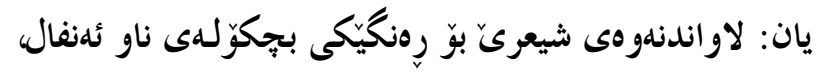

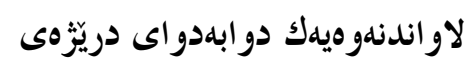

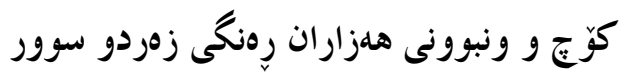

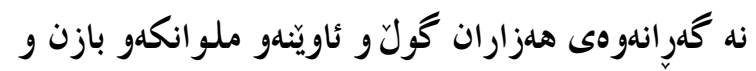

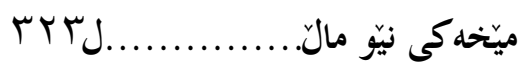

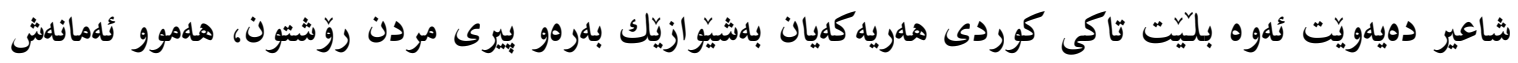

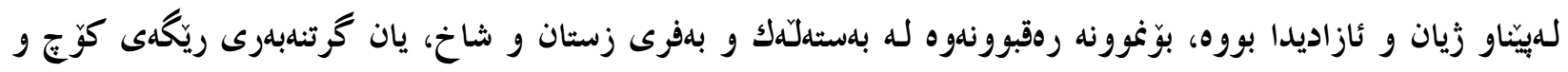

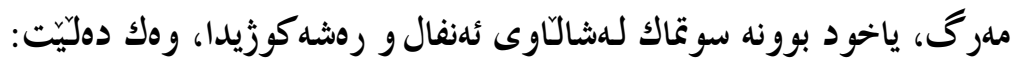
دونكة كان ئلشبوون بلهمردن

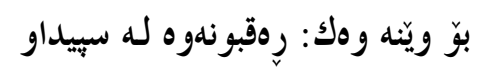

$$
\text { خنكان لدقووليّى شينداو }
$$

سوتان لهشالّاوى سوورودا...................

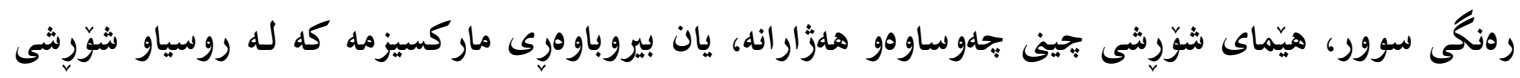

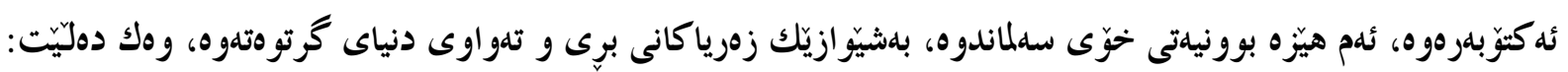

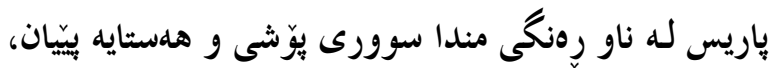

$$
\begin{aligned}
& \text { يه كدم حهكوش سلرو ملى قورسى من نهبوو }
\end{aligned}
$$

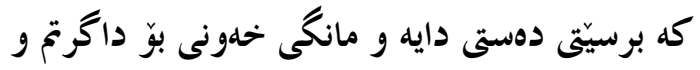

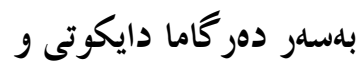

$$
\begin{aligned}
& \text { له دوايشدا مانگ بوو به نان }
\end{aligned}
$$

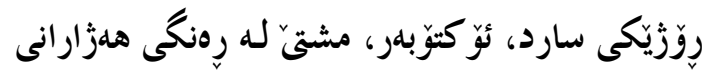

$$
\begin{aligned}
& \text { له مليدانى سووردا تؤو كرد }
\end{aligned}
$$

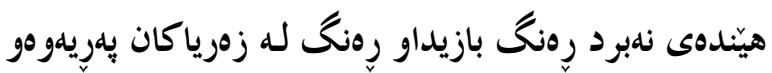

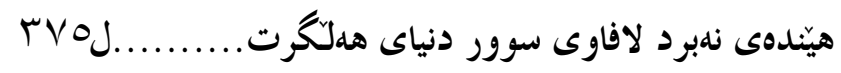

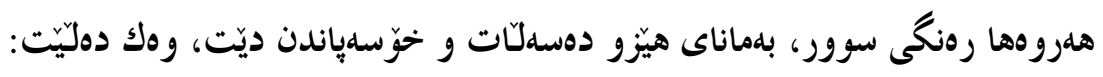

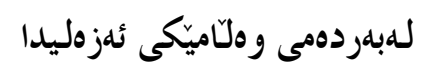


كى ئدتونى فززه بكات بلهبهر دهمى زل هيّزه

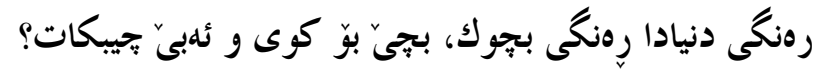
من له بيرمه

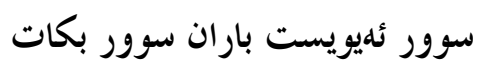
زهرد ئليو يست ئاسمان زهرد بكات بكان

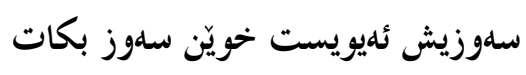

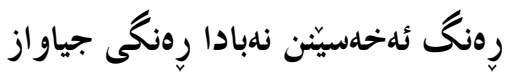

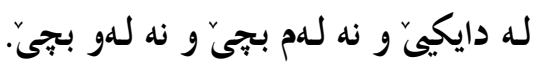

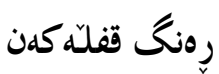
نه بادا رونكگيكى جياواز

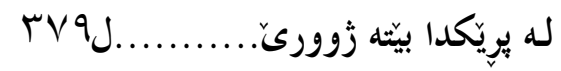

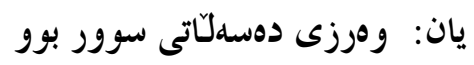
دنيا بووبوو به سوورستان شينيّك ويستى بلشهقامى سووردا برواو

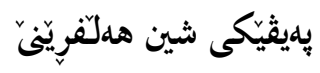

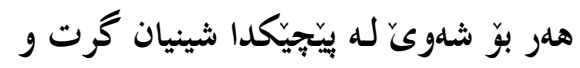

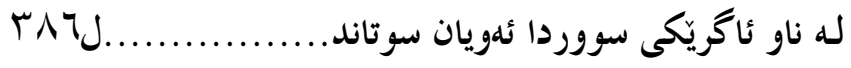

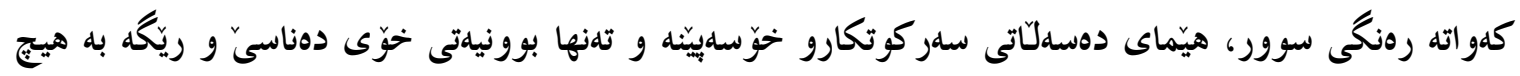

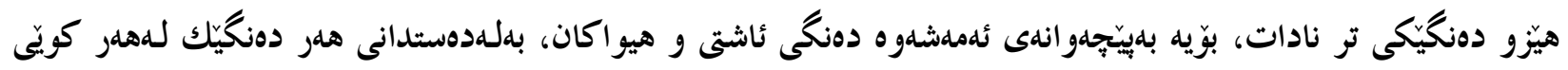

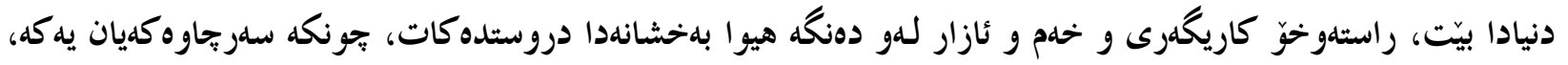
وهك دوليّت:

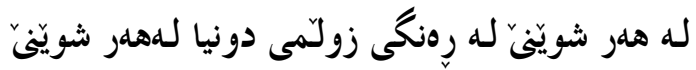

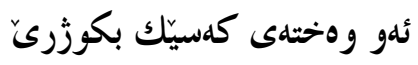

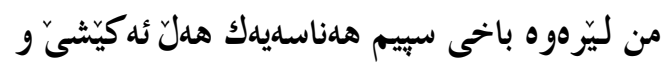

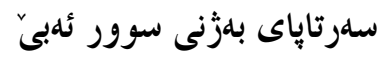

$$
\begin{aligned}
& \text { جهلد نزيكين له يهكةوه................... }
\end{aligned}
$$

$$
\text { ع.رهنكى رِّ: }
$$

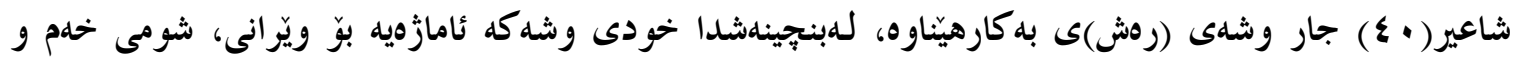

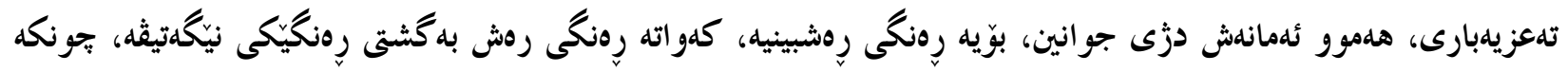




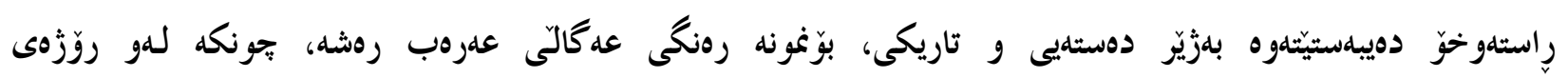

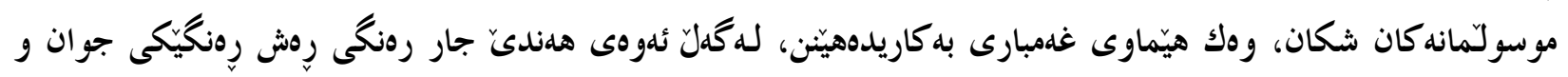

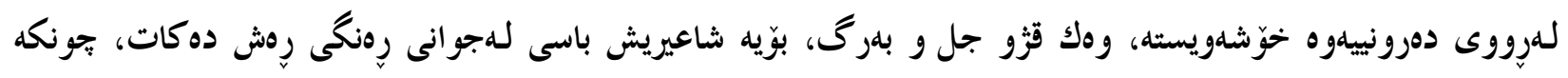
سيفهتيكى ئيستاتيكييه لاى شاعيران.

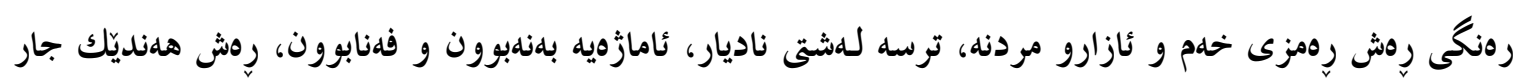

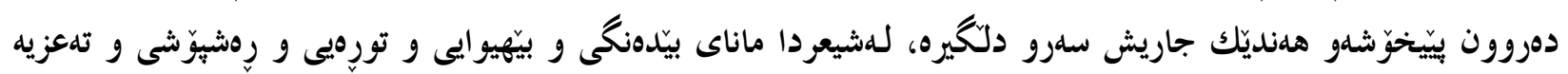
ديّت.

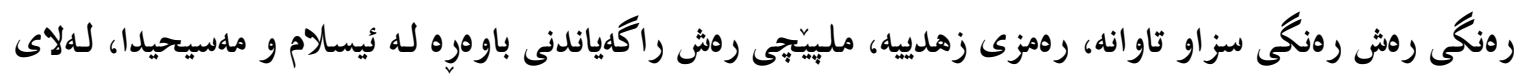

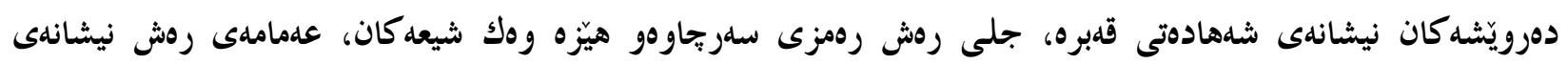

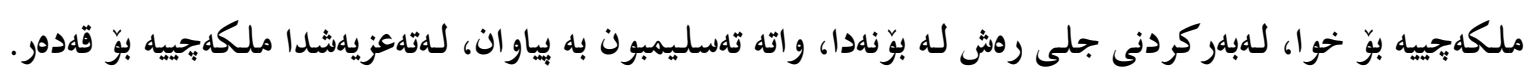

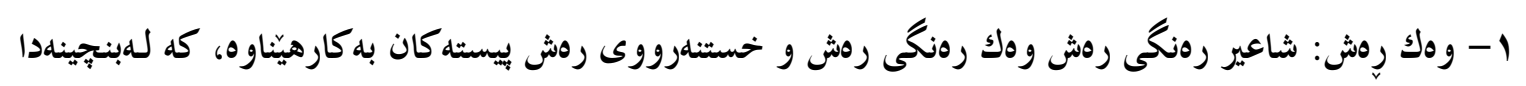

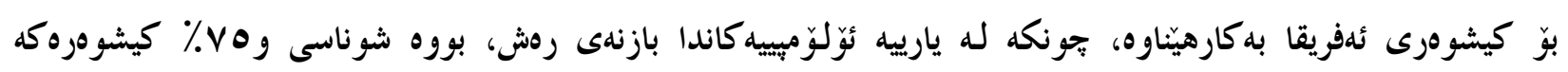

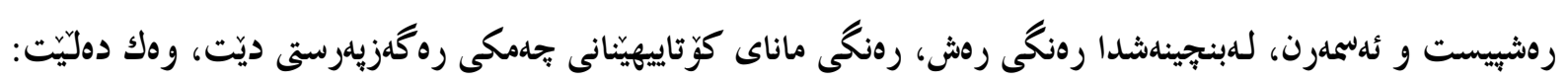

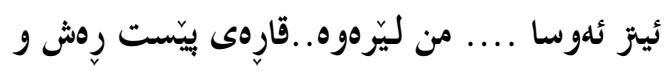

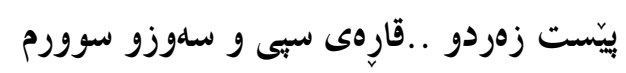

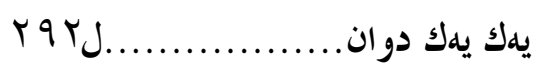

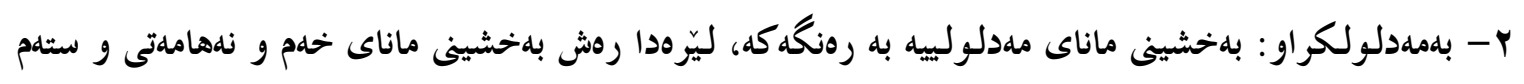

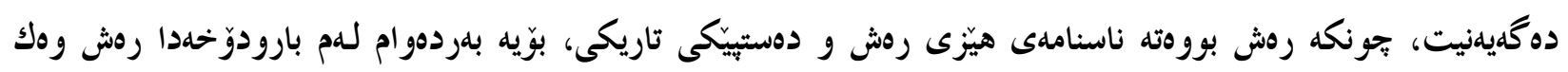
وهرزى زستان دهناسيتّن، وهك دهلّيّت:

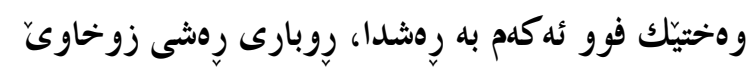

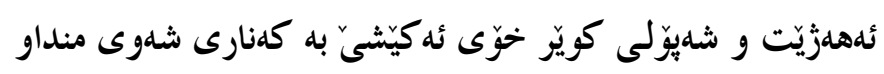

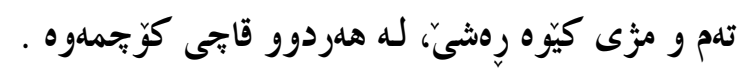

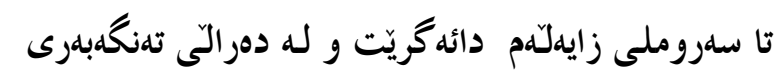

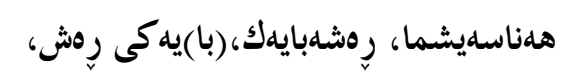

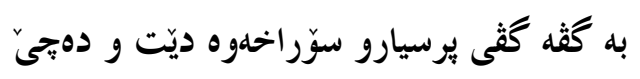

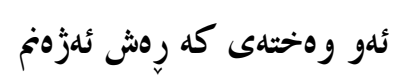

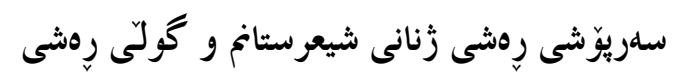

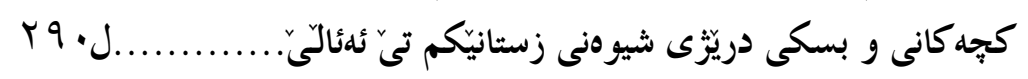

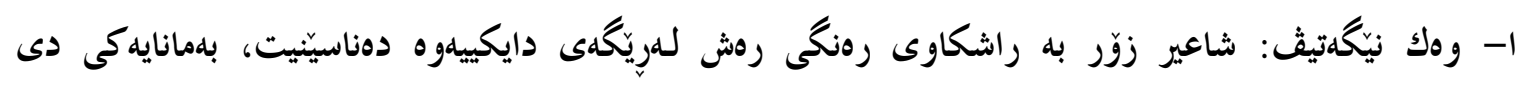

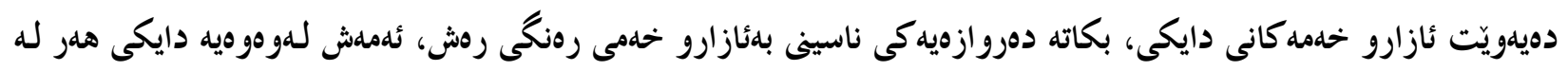




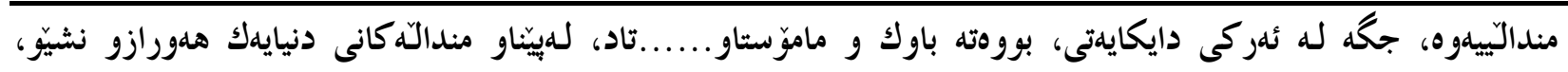

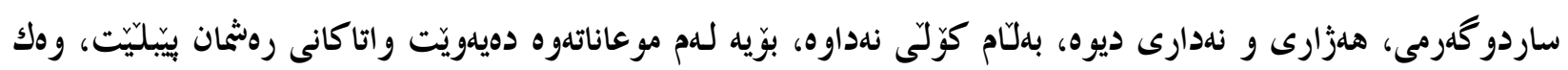

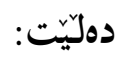

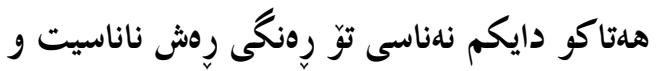

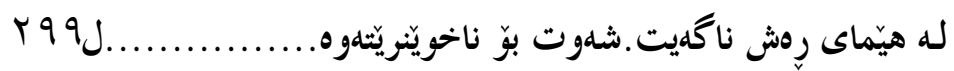

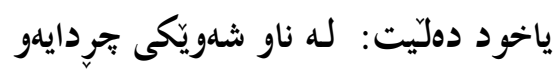

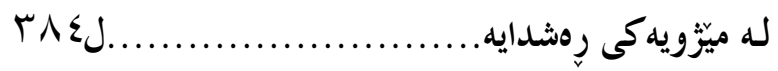

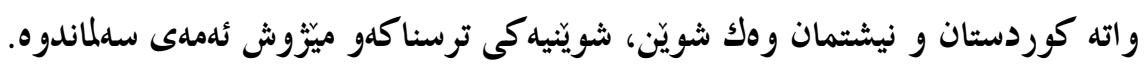

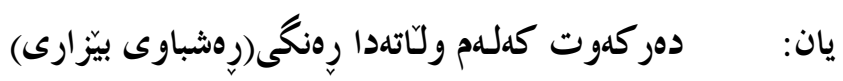

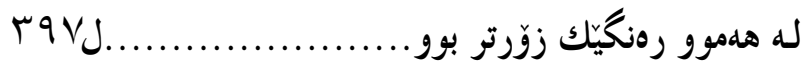

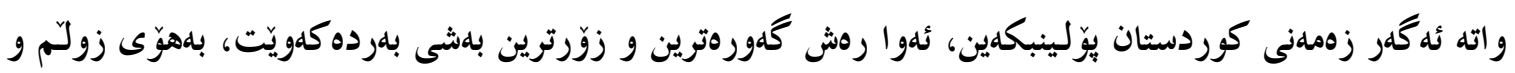

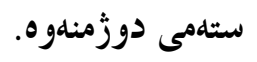

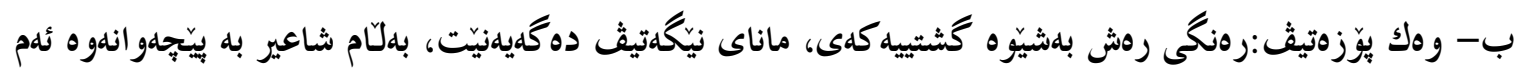

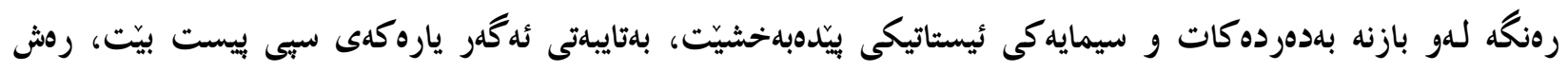
دهبيّنه هيزّى ناساندنى جوانيه كهى، وهك دهوليّت:

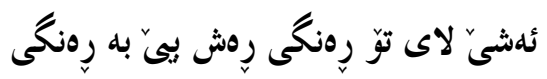

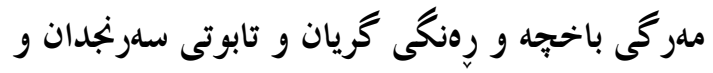

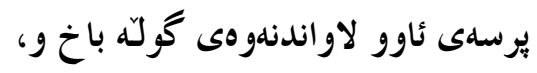

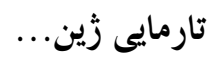

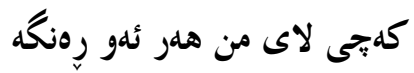

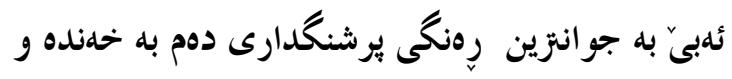

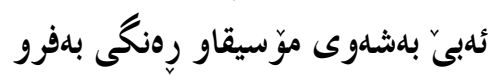

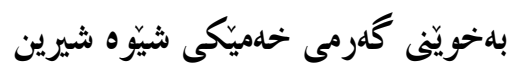
وهختيّك يارم، كولى سبيم

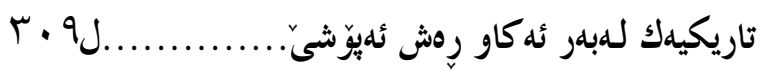

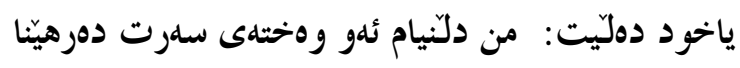

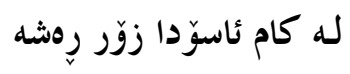

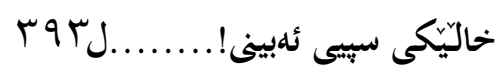
ه.رونكى سبى: 


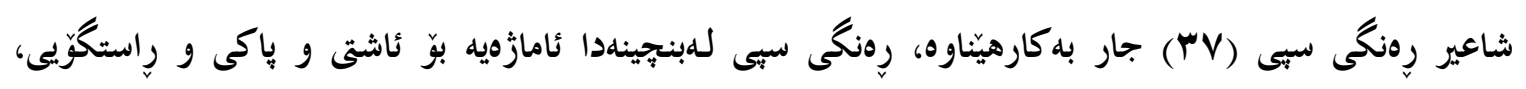

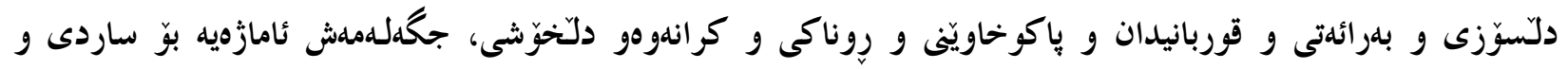

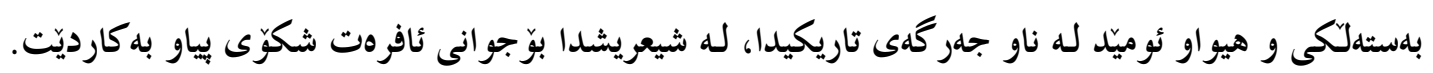

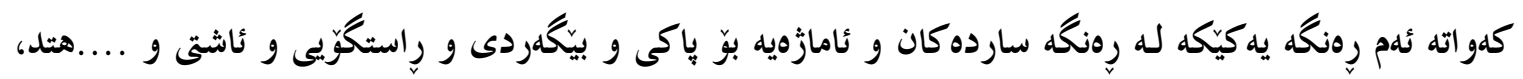

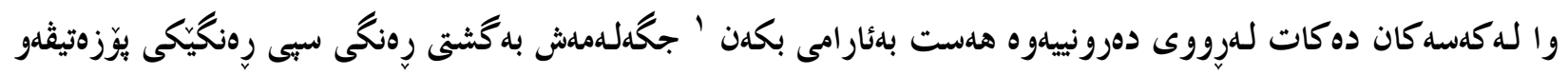

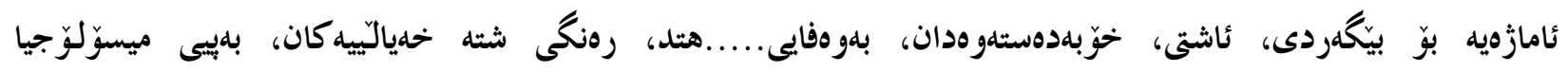

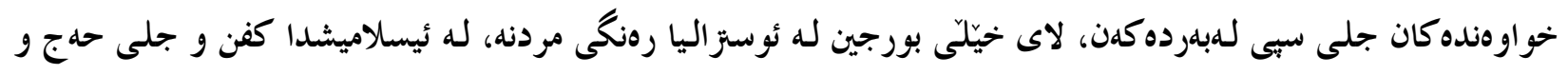
علمره سبييه.

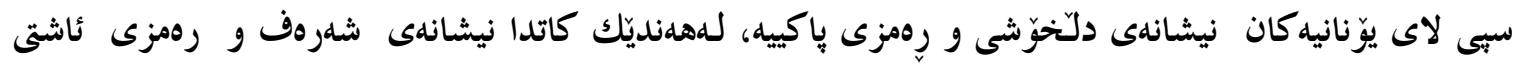

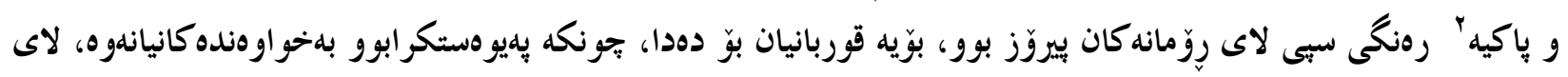

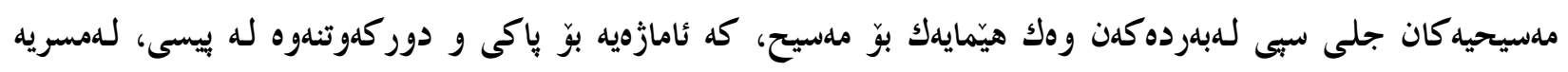

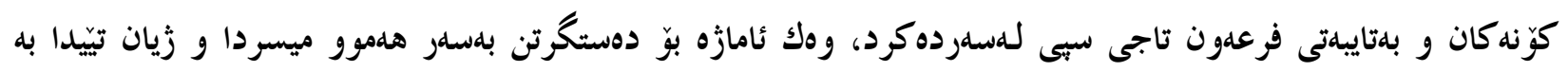

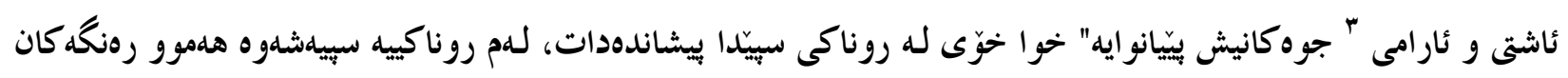

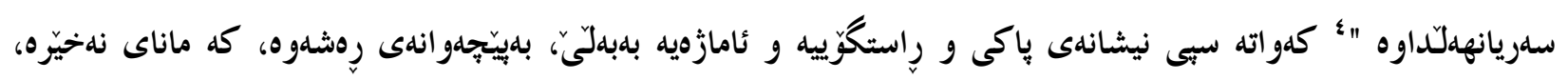

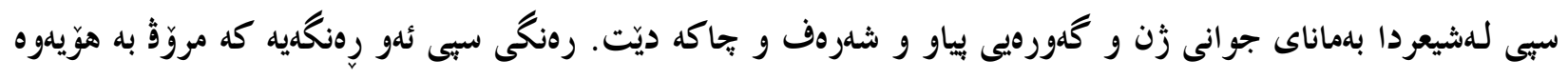

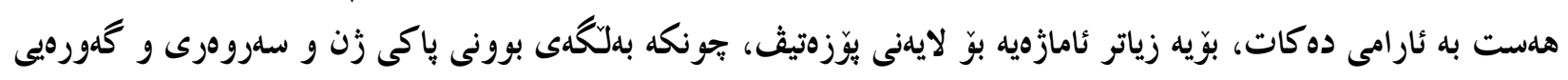

ا. وهك رهنكى سبى:ملبdست له رهنگى سبى، رهنگى كيشوهرى بلهتنلهكى باشورهو ناسراوهبd(ئلنتاركتيكا)و

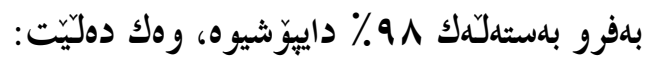

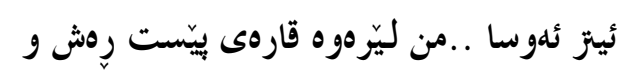

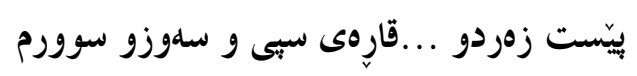

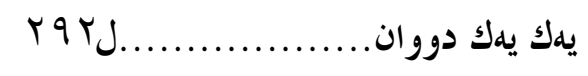

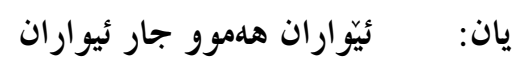
له زَيْلا يوّله مهل:رهش، سبى، خالَ خحالَ و زهرد باو و يُمهيى ونارنجى

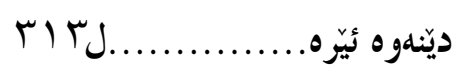

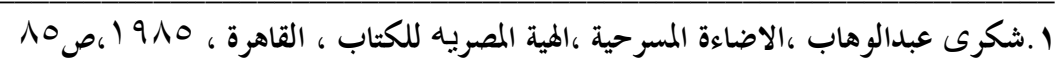

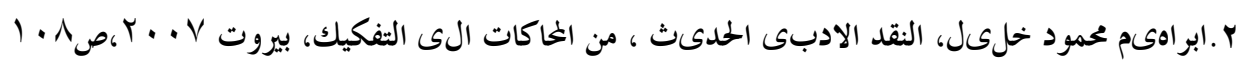

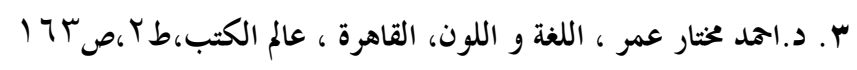

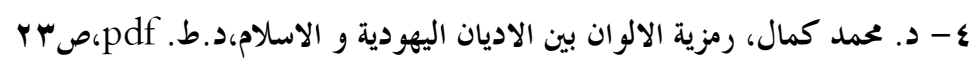




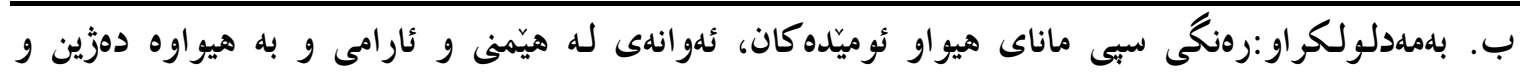

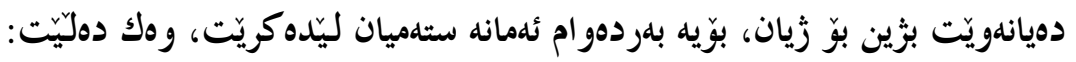

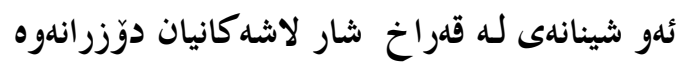

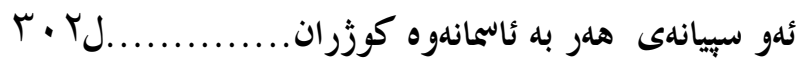

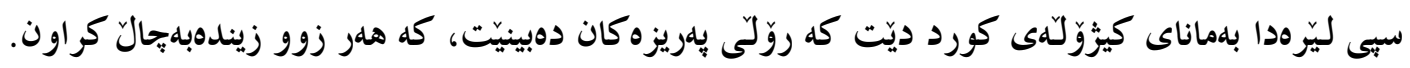

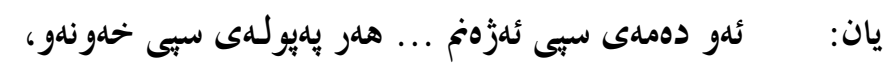

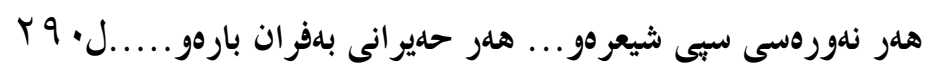

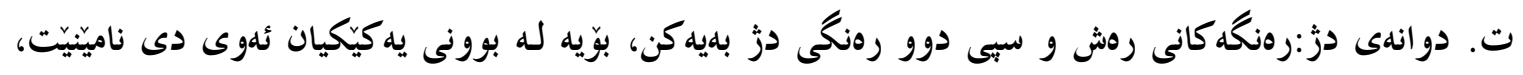

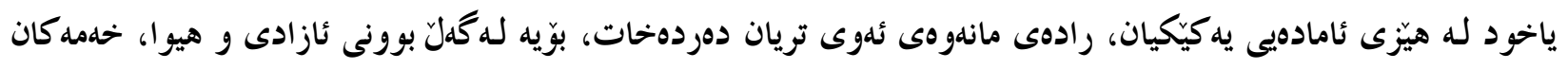

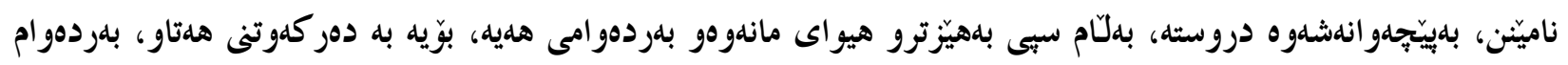

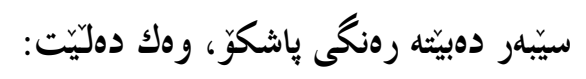

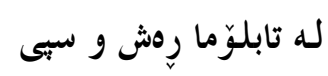
بلهراييهك له دهشتى زهين دروست نئه كهن نيوهى هلتاو ،نيوهى سيّبلر

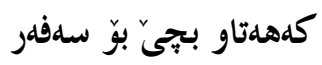

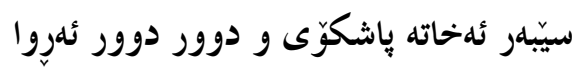

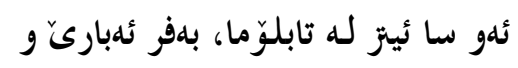

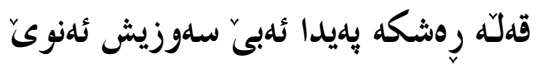
ديسانهوه جاريّكى تر رهش و سبى ليى به دواى يهكتزدا ديّنهوه ئلمجارهيان ئهويان قزّى زنه كه(با) دهيبات و و

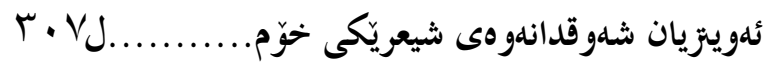

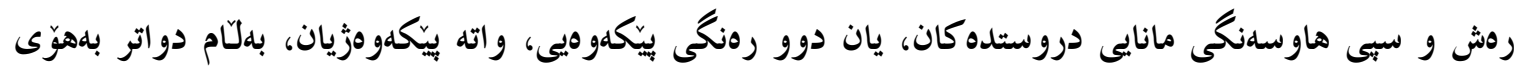

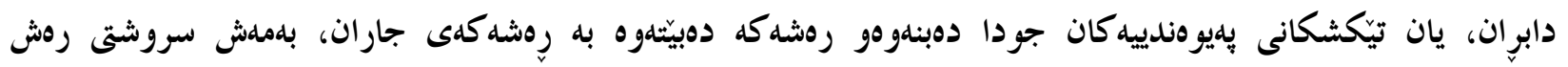

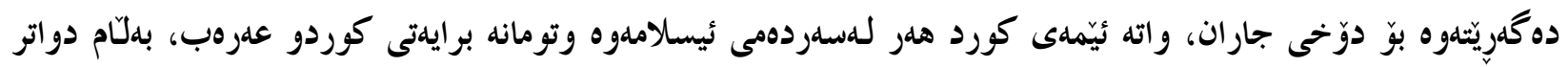

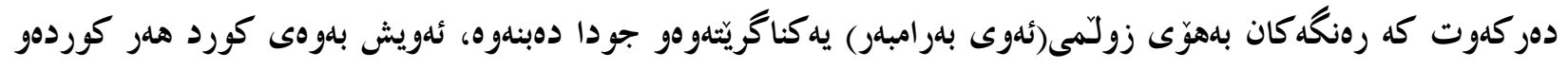
عهرهبيش هلر علرهب.

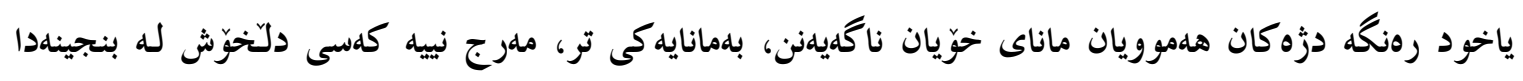

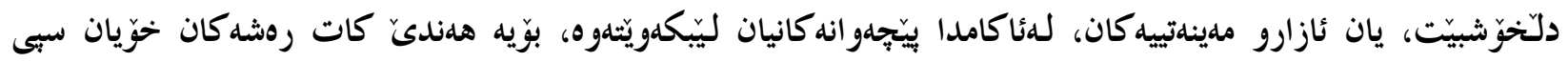
دهنوينن و سبيدكانيش بلهdمان شيّوه، وهك دهليّت : 


$$
\begin{aligned}
& \text { لـ له تابلوَما رهش و سبيى }
\end{aligned}
$$

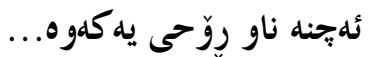

$$
\begin{aligned}
& \text { جارشيّو هانى روالحّت فريّ ئهدهن }
\end{aligned}
$$

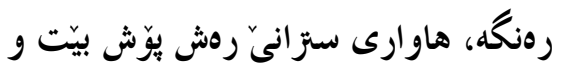

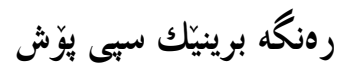

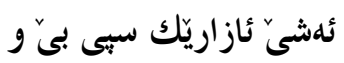

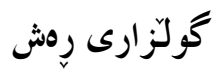

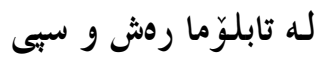

$$
\begin{aligned}
& \text { من هdندى جار ..... رهشه كانم يىّ ئه كهنن و }
\end{aligned}
$$

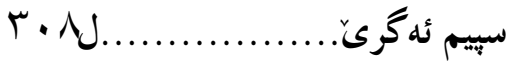

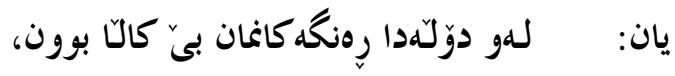

$$
\begin{aligned}
& \text { رهنكة كانمان خلهويان كراسى سبى و }
\end{aligned}
$$

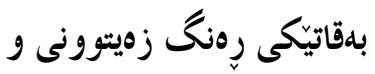

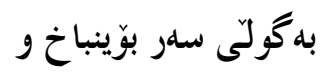

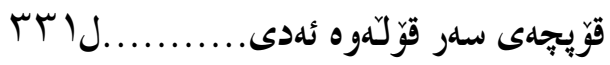

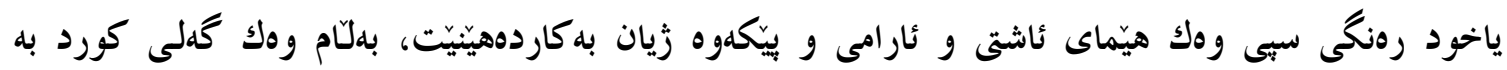

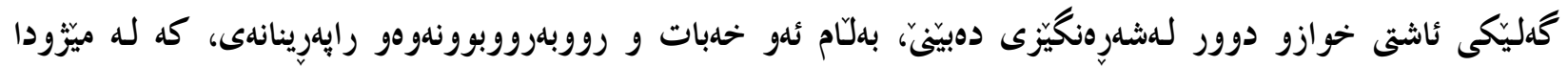

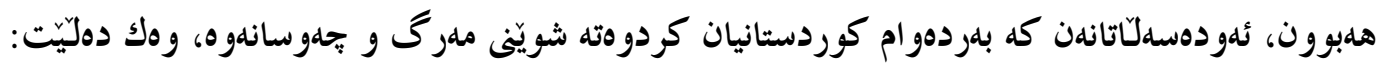

$$
\begin{aligned}
& \text { من بيبكهم لله نيشتيمانى ناو خويَّاو } \\
& \text { ئلهو هلموو شيعرهى بيى نوسيم }
\end{aligned}
$$

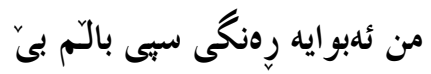

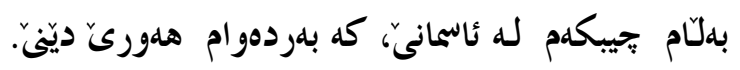

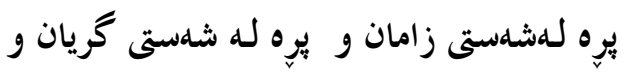

دوو كهل ئه كا به قهدهرم و جّاوى ميّزّووم

هلر به تdنها بلرايى رهنكى هلمووتاو

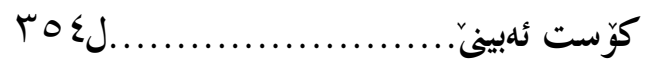

$$
\begin{aligned}
& \text { ياخود دهلّيت: وا راهاتووم شهو انيش } \\
& \text { ئه كمرى شهوى بهفرانبار بور } \\
& \text { ئلو شهوانه، شهوى سبى، نهدهم بهكةس برس }
\end{aligned}
$$


بجمه بلهر بهنجرهى زوورى

$$
\text { تلنياييم و }
$$

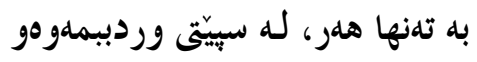

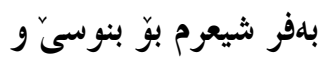

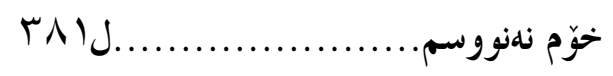

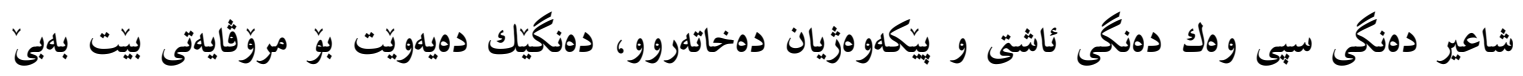

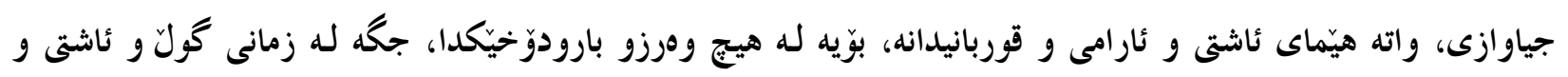

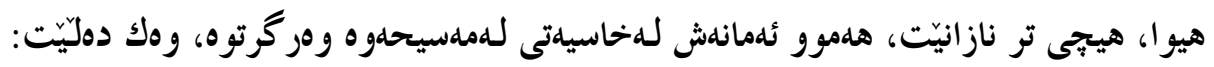

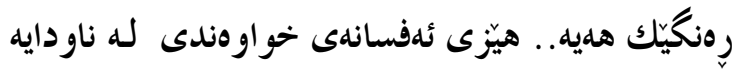
سيحره كانى علساى موساى لله ناو دهستاو

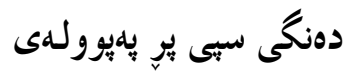
مdسيحيشى له دهنگدايه

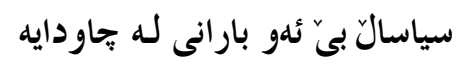

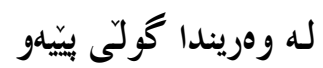
له ناو وهرزى نابيناشدا

r^९」.... ئلهو هلناوى جر اى تيايه..

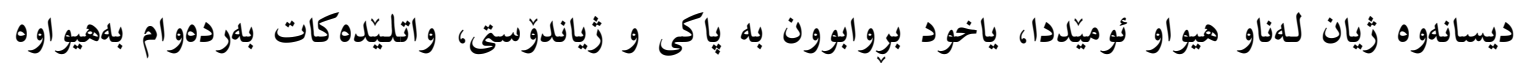

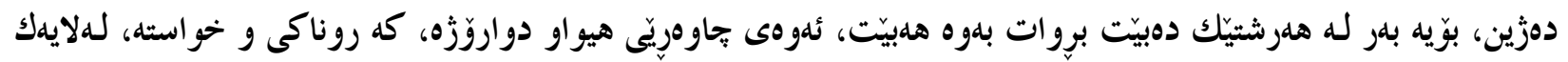

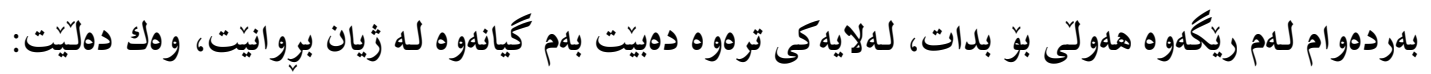

$$
\begin{aligned}
& \text { سلرت بكه به رِوّشنايى ناو سيّيّدا } \\
& \text { جاوت له بنيا بكهوه } \\
& \text { من دلّنيام ئهو وهختهى سهرت دهرهينّا } \\
& \text { لـه كام نُاسوّدا زوَر رهشه } \\
& \text { خالّيكى سبى ئهبينى........................ }
\end{aligned}
$$

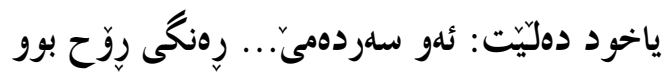

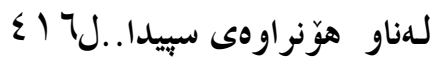$$
\text { 7. } 7
$$ 


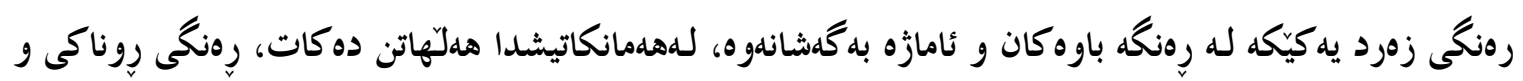

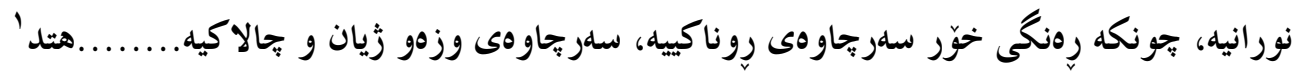

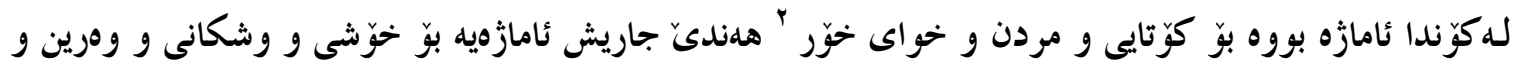
كوّتايى و مردن...... هتد

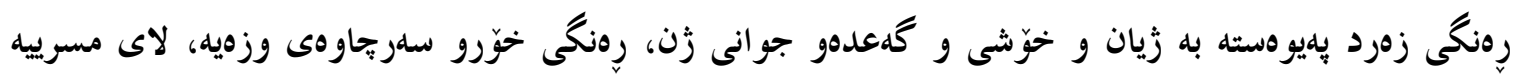

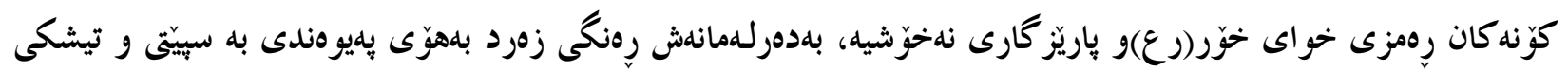

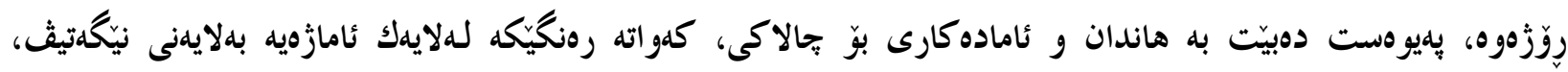

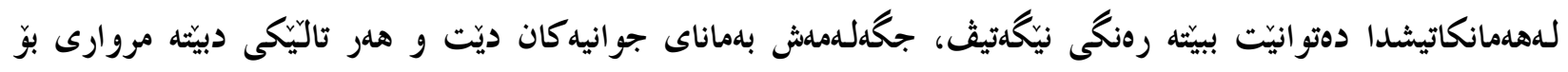

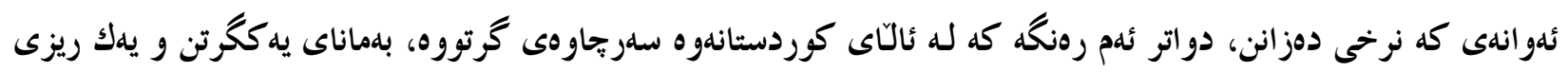
ديّت، يان يهك بار بحليى خاك و هيز هكان.

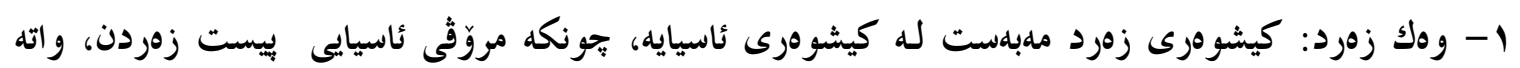

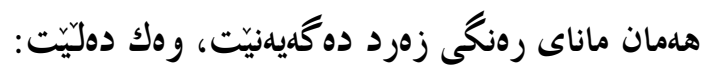

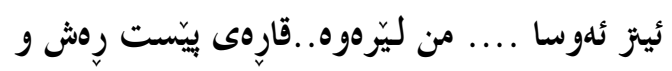

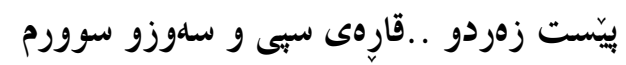

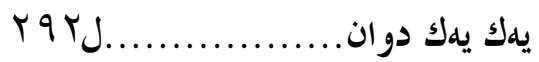

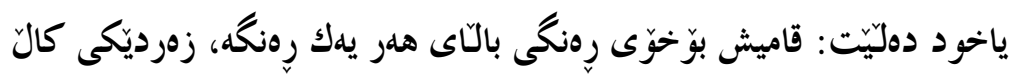

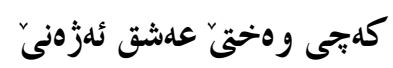

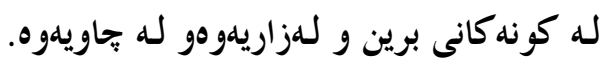

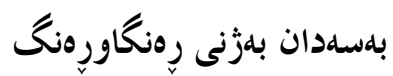

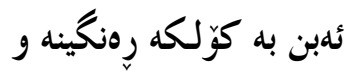

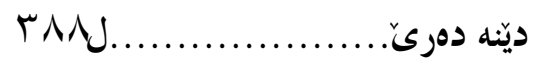

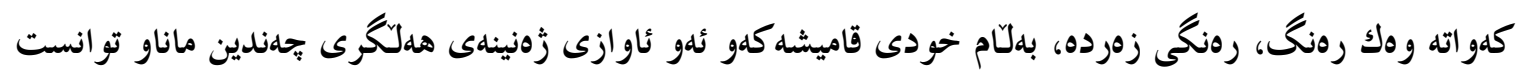
و عيشق و......تاد

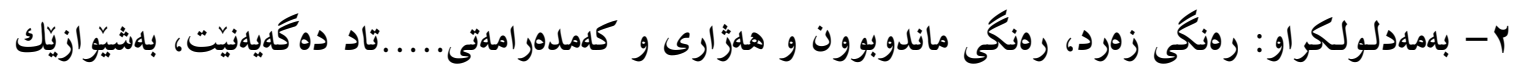

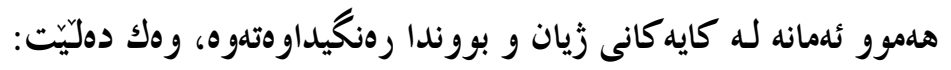
بلبر سيلتى رِنكيّكى هلبوو، درو جحموش، 


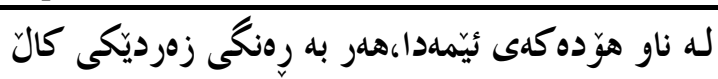
للهسهر ليو و للهسهر گُمدنى دايكم و للهسهر سهبلتهى نانه كهو للهسهر كوّناى خوشكه كهم و للهدهفتهرى رهسيمى مندا

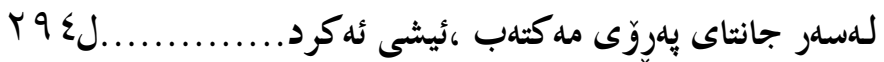

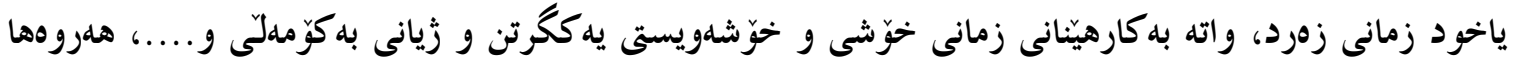
لهبلرامبهريشدا زمانى سووريش زمانى خوّشهويستييهكى جهريئانهيه، بلمانايهكى تر زهرد للهرووى كارنامهوه وهك سورور

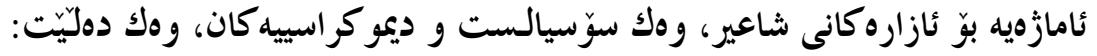

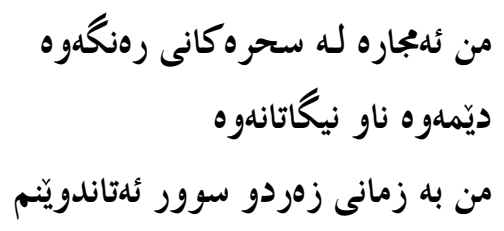

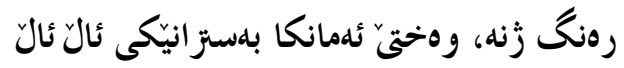

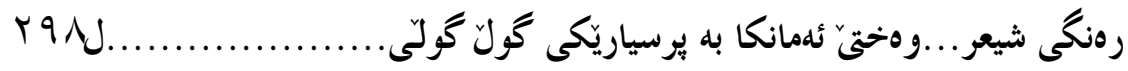

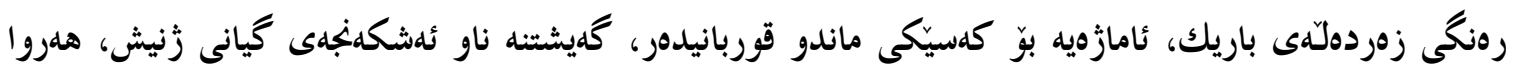

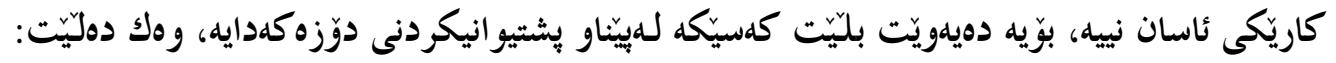

$$
\begin{aligned}
& \text { لهريى رهنكيّكى زهردولّدى باريكهوه }
\end{aligned}
$$

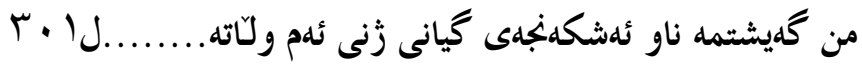

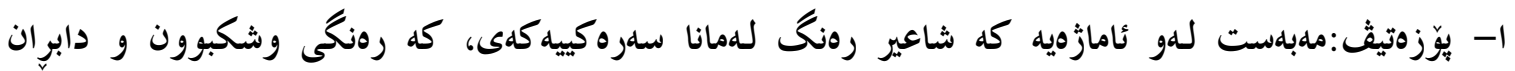

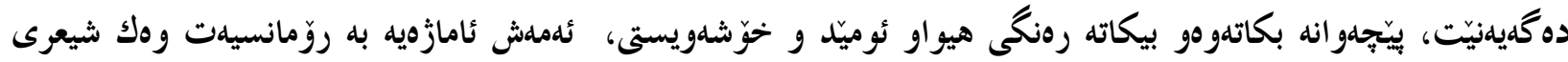

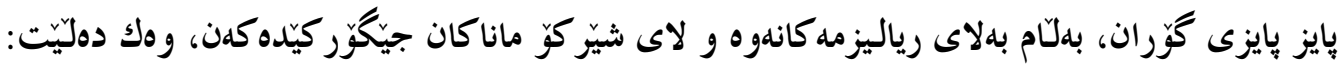

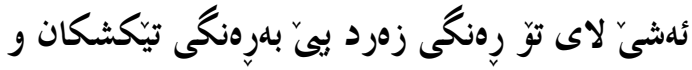

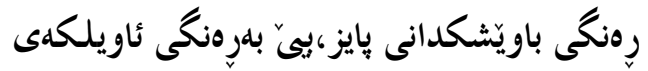

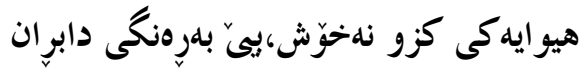

$$
\begin{aligned}
& \text { له نيّو ان دوو كُّرانى و دوو بالَّدهو دوو دلّداردا. } \\
& \text { كهنجى لاى من هdر ئهو رِنكه }
\end{aligned}
$$

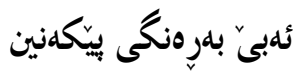

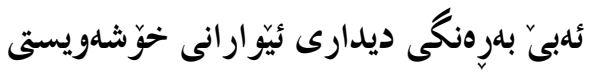

$$
\begin{aligned}
& \text { به مانكُشهوى خله بله بينين }
\end{aligned}
$$

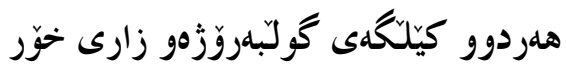

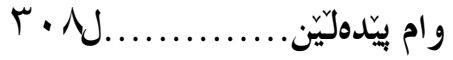




$$
\begin{aligned}
& \text { ياخود دهليّت :من لله وهرزى دابِ اندا }
\end{aligned}
$$

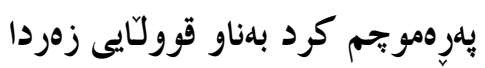

$$
\begin{aligned}
& \text { زهرد كرتمى و } \\
& \text { زهرد رِايكيَشام بوّ بنهوه ورن } \\
& \text { للهو ساتهوه من بووم به زهرده ماسييهك }
\end{aligned}
$$

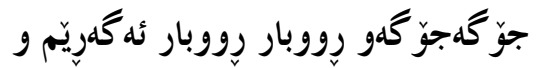

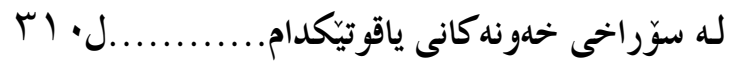

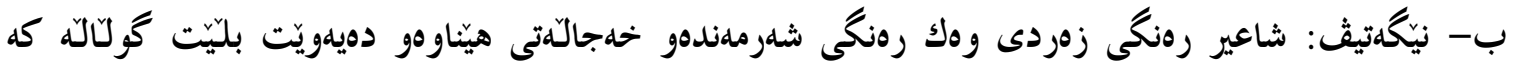

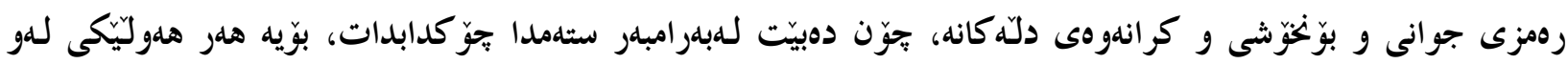

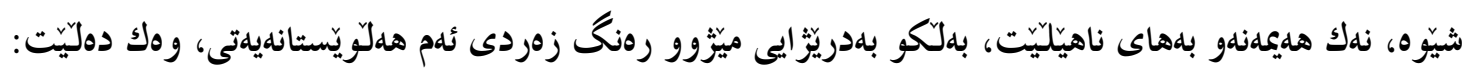

$$
\begin{aligned}
& \text { كو لَّلّهيهك } \\
& \text { بوّ توترِ كيّك نوشتايلهوه } \\
& \text { دهستى ماج كرد } \\
& \text { كه ليبِوَوهو هلستئايهوه } \\
& \text { رهنكى سوورى } \\
& \text { رزّابووه بله بيّى توترك و } \\
& \text { هلتا مردن }
\end{aligned}
$$

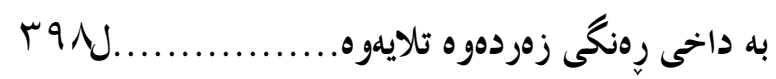

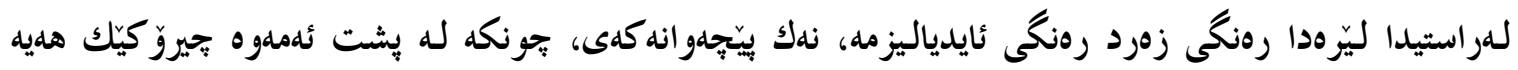

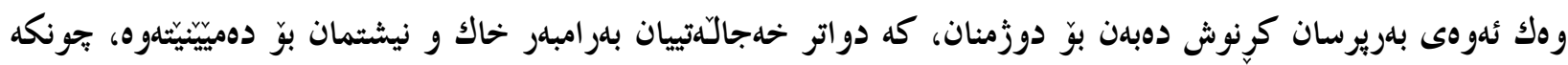

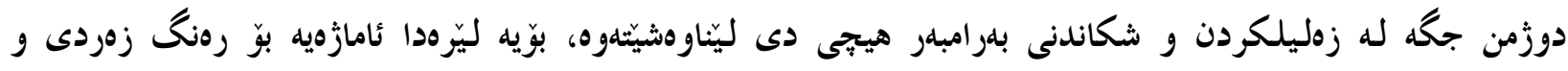




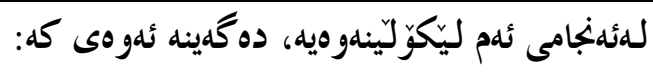

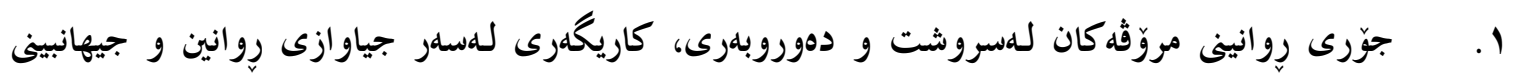
كهسd كهوه هdيه.

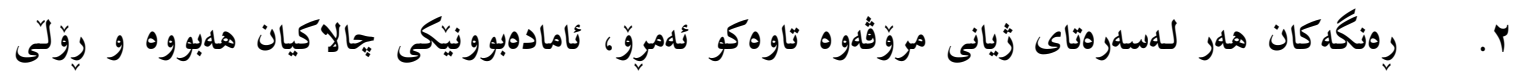
جياوازيان گيّرِاوه.

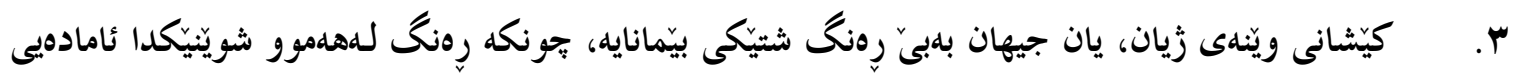
و ورَّلَى هليه.

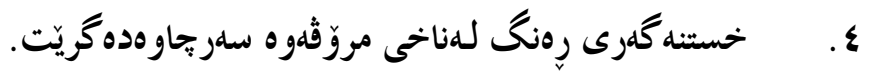

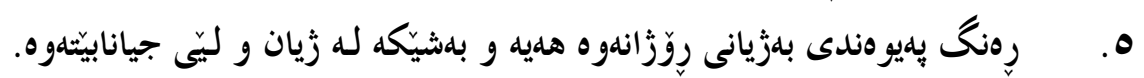
7.

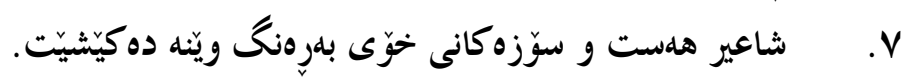

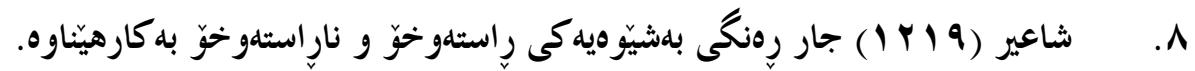

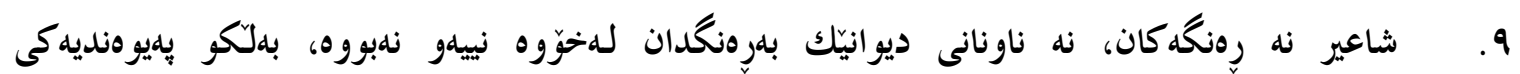

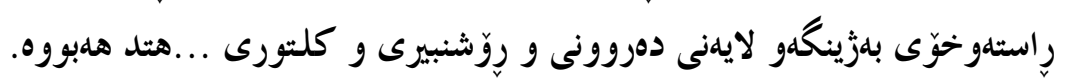

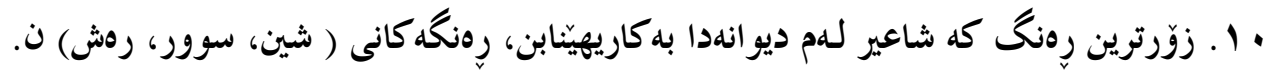

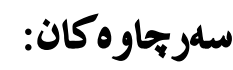

\section{يلهمه: كوردييه كان:}

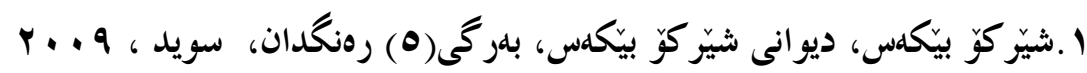

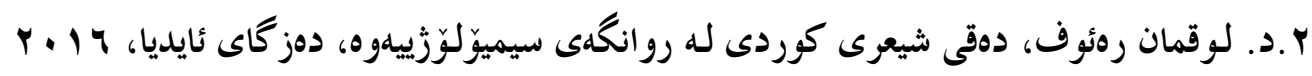

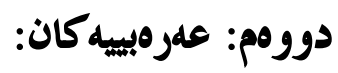

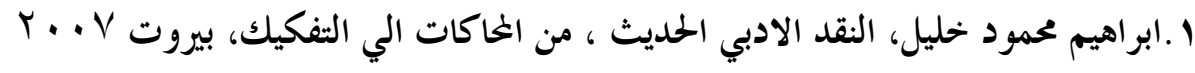

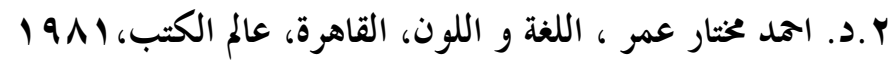

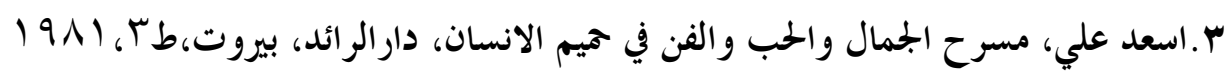

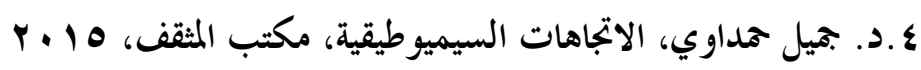

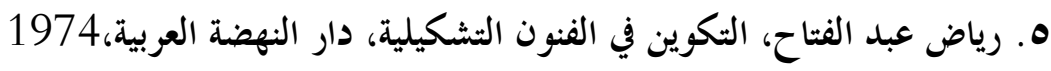

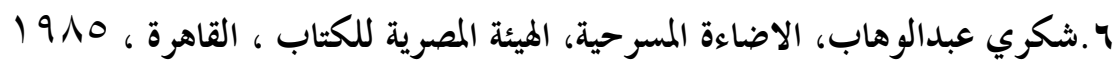

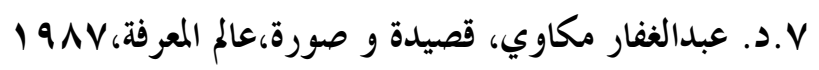




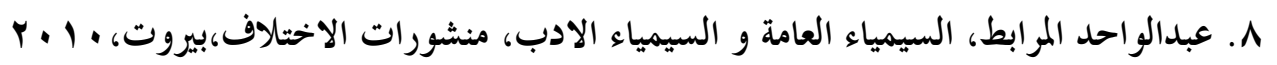

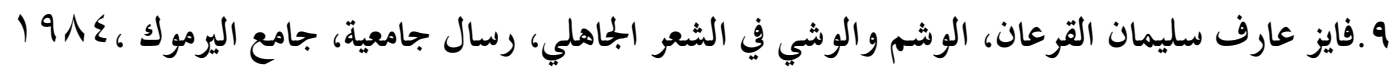

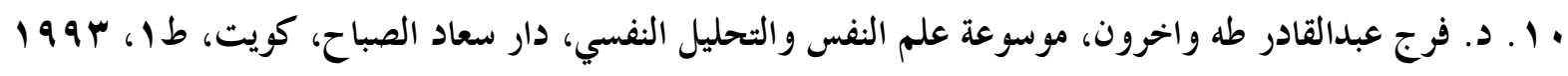

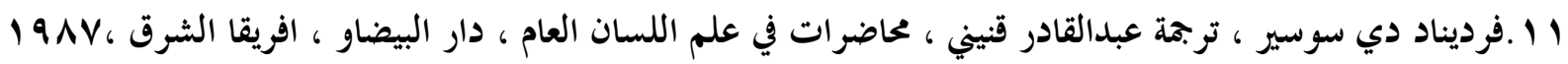

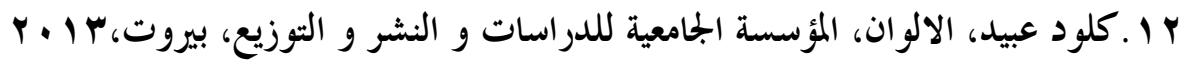

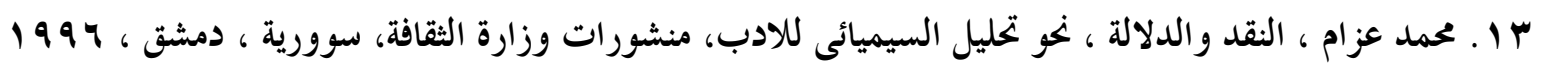

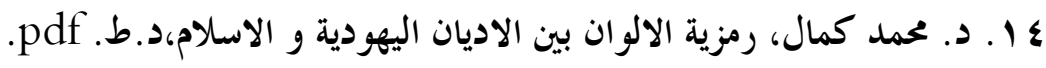
سيّيلم: فارسييه كان:

ا.حمد رضا عمران بور، اهميت عناصر و ويذطي هاي ساختاري واذة در طزينيش واذةكان شعظ، نشرية طوهر طويا،

\section{كُوْار:}

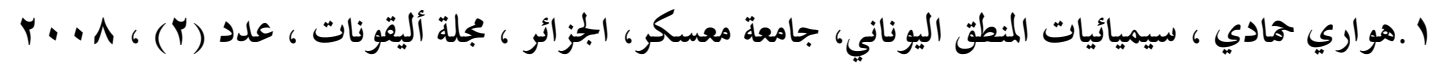

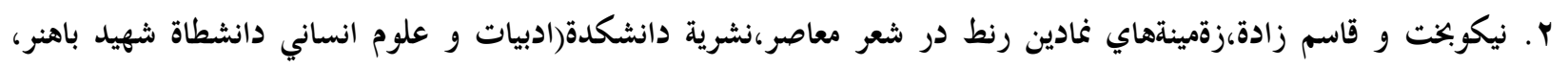

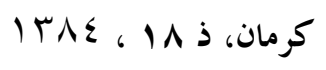

نامه:

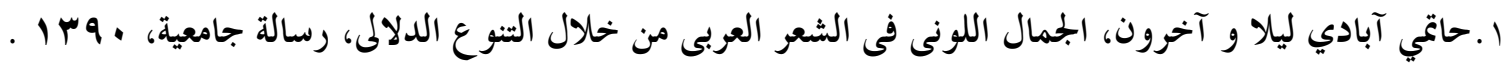

